Isabella Romitelli

Variabilidade espacial nos estoques de carbono em paisagens fragmentadas da Mata Atlântica

Spatial variability in carbon stocks in the Atlantic Forest fragmented landscapes

São Paulo

2014 
Isabella Romitelli

\title{
Variabilidade espacial nos estoques de carbono em paisagens fragmentadas da Mata Atlântica
}

\author{
Spatial variability in carbon stocks in the \\ Atlantic Forest fragmented landscapes
}

\author{
VERSÃO CORRIGIDA \\ Dissertação apresentada ao Instituto de \\ Biociências da Universidade de São Paulo, \\ para a obtenção de Título de Mestre em \\ Ciências, na Área de Ecologia.
}

Orientador: Prof. Dr. Jean Paul Metzger

São Paulo

2014 


\section{Ficha Catalográfica}

Romitelli, Isabella

Alta variabilidade e baixos estoques de carbono de florestas tropicais em paisagens antropizadas / Isabella Romitelli ; orientador Jean Paul Metzger. --. São Paulo, 2014.

$64 \mathrm{f}$.

Dissertação (Mestrado) - Instituto de Biociências da Universidade de São Paulo. Departamento de Ecologia.

1. Estoque de carbono. 2. Florestas tropicais. 3. Mata Atlântica. 4. Biomassa acima do solo. 5. Paisagens fragmentadas. I. Universidade de São Paulo.

Instituto de Biociências. Departamento de Ecologia. II. Título.

\section{Comissão Julgadora:}

Prof. Dr. Jean Paul Metzger

Orientador 


\section{Dedicatória}

Ao meus pais, por me proporcionarem o ambiente de estudo desde semente e me incentivar à pesquisa. 


\section{Epígrafe}

Who's to say

What's impossible?

Well they forgot

This world keeps spinning

And with each new day

I can feel a change in everything

And as the surface breaks reflections fade

But in some ways they remain the same

And as my mind begins to spread its wings

There's no stopping in curiosity

I wanna turn the whole thing upside down

I'll find the things they say just can't be found

I'll share this love I find with everyone

We'll sing and dance to mother nature's songs

I don't want this feeling to go away

Who's to say I can't do everything?

Well I can try, and as I roll along I begin to find

Things aren't always just what they seem

I want to turn the whole thing upside down

I'll find the things they say just can't be found

I'll share this love I find with everyone

We'll sing and dance to mother nature's songs

This world keeps spinning

And there's no time to waste

Well it all keeps spinning spinning

Round and round and upside down

Who's to say what's impossible and can't be found?

I don't want this feeling to go away

Jack Johnson, Upside down 


\section{Agradecimentos}

Definitivamente esta é a parte mais difícil de escrever no mestrado. Interessante que é a única em que posso escrever livremente, pois não exige nenhuma formatação. Pensando nos 28 meses de duração deste projeto, chego à conclusão que tenho muita sorte por encontrar tantas pessoas boas em meu caminho, à quem devo o sucesso desta empreitada!

Ao meu orientador e professor Jean, muito obrigada pela confiança em mim desde o início. Quando despretensiosamente escolhi sua disciplina para cursar como aluna especial, encontrei em um pesquisador e professor características as quais me identifiquei e admiro. Agradeço principalmente pelo desafio de trabalhar com florestas e permitir que o fato de ser bióloga marinha não fosse um impedimento para realizá-lo.

Agradeço aos membros do meu comitê de acompanhamento, Ale Uezu, Jean e Simone. Essa interação foi fundamental para bom andamento do projeto. A complementariedade das habiliades de cada um construiu um projeto sólido, o que me deu muita segurança de realizá-lo.

Obrigada à Ká, por ser minha companheira desde o ínicio. Levo comigo uma verdadeira amizade e exemplo de companheirismo. Obrigada ao Chico, partner de biomassa acima do solo, que com as discussões acerca do tema, me proporcionou bastante aprendizado, descontração e enriquecimento do vocabulário.

Aos meu incríveis ajudantes de campo, que não só ajudaram a abraçar árvores, mas colaborarm muito para o desenvolvimento da logística de se fazer um campo, doando seu tempo, energia e até carros particulares! Obrigada Ká e Chico (de novo), Cíntia, Gui, Camila, Vivi, Greet, Renê, Amanda e Lari.

Agradeço ao Instituto de Pesquisas Ecológicas e toda sua equipe, em especial ao Ale Uezu e Ivete, que me acolheram e me forneceream o alojamento ideal para a realização do meu campo. Obrigada à toda equipe, sempre solicita às minhas necessidades. Agradeço ao meu mateiro oficial, Cido, que me deu bastante segurança e condições para a realização do meu trabalho, além de muito aprendizado. 
À Greet e Paula por me ajudarem com dicas fundamentais para a análise de dados. Ao Renê, Nati, Ká e Thaís por me ajudarem na criação final da dissertação e ao Renato Lima que me ajudou com a caracterização de florestas secundárias.

Ao Programa de Pós-graduação em Ecologia da Universidade de São Paulo e ao Instituto de Biociências por oferecer disciplinas e condições para meu aprendizado. Consigo ver uma grande diferença em mim entre antes e depois do mestrado e acredito que isto se deve, além do meu projeto, à todas atividades que realizei neste período, como fazer parte da comissão do EcoEncontros, comissão do auxílio individual da PROAP/ CAPES e monitoria PAE. Agradeço aos professores, que através das disciplinas e conversas informais me proporcioram muito aprendizado, o que foi essencial para execução do projeto e da minha formação como mestre.

Aos meus amigos do departamento de ecologia e do LEPaC pela recepção, aprendizado, momentos de descontração e parceria em trabalhos. Sou muito feliz por tê-los como amigos e companheiros de trabalho. Obrigada Nati, Feli, Fer, Juarez, Lari, Paula, Amanda, Lê, Ká, Chico, Thaís, Liz, Greet, Chico, Adrian, Ká, Mila, Júlia, Kate, Ju, Letícia, Marina, Soly, Cata, Pâmela, Vivi, Camila, Betânia, Tati e Renatcho.

A todos os funcionários do IB, em especial à Vera e ao Welington Bispo, pelas constantes ajudas com procedimentos da pós-gradução e com computadores.

Ao apoio financeiro da Coordenação de Aperfeiçoamento de Pessoal de Nível Superior (CAPES), que me forneceu a bolsa de mestrado e verba para a realização da minha coleta de dados em campo.

Agradeço às pessoas que não me ajudaram diretamente no projeto, mas com certeza me fizeram muito mais forte e feliz para superar todos os desafios. Ao meus companheiros de LEPaC (supracitados), meus amigos da graduação, que com poucos, mas memoráveis encontros, vocês se fizeram muito presentes durante esta fase. Obrigada Fofuxa, Pink, Margarida, Cyro, Creusa, Figura, Mudinho, Lumbriga, Papeixe, Tigrão, Shibinha, CPV e Café. E agradeço às minhas amigas de toda vida Roberta, Bru, Ju e Rê pelos momentos de relaxamento. 
Obrigada ao Feli que me apresentou para o HAND BARANGO, time de handebol da biologia. Sinto por não ter conhecido esta experiência antes, mas certa de que além de treinar e jogar handebol, conheci grandes meninas (Gli, Cris, Murf, Ctrl+C, Ctrl+V, Barbie, Isaura, Ibiza, Tonks, Felícia, Farelo, Charlinha, Orgia, Kelly, Gaba e Sol) e um meninão (Vitão), que me receberam de braços abertos, sem preconceito de idade. Obrigada time!

À meu pai por acreditar no meu potencial e me apoiar financeiramente e emocionalmente. Obrigada Nina, Fê, Rafa e Tereza pela curiosidade do meu trabalho e esforço para entendê-lo. Vocês são meu porto-seguro e meu referencial de vida. Agradeço ao Renê, Zezinho, Rô e Belle por tornarem vosso lar, meu segundo lar. Sou grata por cada minuto de aprendizado, descontração e pelos ótimo dias de verão em Ubatuba. Sofia, sou grata por ser minha companheira desde o estudo da prova de ingresso até esta dissertação, tomara que no futuro exista uma tecnologia que faça você ler isso.

Por fim, agradeço a quem foi meu companheiro desde antes da ideia do mestrado e que a cada dia, me fortaleceu e contribui para execução do projeto, até o dia de fechamento desssa dissertação. Obrigada Renê, por me ajudar a enfrentar cada desafio de cabeça erguida e reconhecer cada vitória conquistada.

Quis aproveitar que a formatação é livre e decidi fazer um (:), para demonstrar minha felicidade em encerrar esta fase, totalmente satisfeita com o produto final e com todos que conhecei e convivi. 


\section{Índice}

Introdução geral 1

Capítulo único $\quad 7$

"High variability and low carbon stocks of tropical forest in human dominated landscapes"

$\begin{array}{ll}\text { Abstract } & 7\end{array}$

1. Introduction $\quad 8$

2. Materials and methods 11

2.1. Study site and sampling design 11

2.2. Inventory protocol 13

2.3. Allometric equations to estimate 13

aboveground biomass (AGB)

2.4. Explanatory variables $\quad \mathbf{1 4}$

2.5. Statistical analysis $\quad \mathbf{1 5}$

3. Results 17

3.1. Above-ground biomass estimation 17

3.2. Factors influencing AGB 17

4. Discussion 18

5. Conclusions 24

6. Figures 26

Figure $1 \quad 26$

Figure $2 \quad 27$

Figure $3 \quad 28$

Figure $4 \quad 29$

Figure $5 \quad 30$

Figure $6 \quad 31$

7. Tables 32

Table $1 \quad 32$

Table $2 \quad 33$

Table $3 \quad 33$

Table $4 \quad \mathbf{3 4}$

Conclusões gerais 36

Resumo 39

Referências bibliográficas $\quad 40$ 


\section{Introdução geral}

As florestas tropicais, caracterizadas pela alta biodiversidade, têm sofrido intensa transformação ao longo dos últimos anos (Achard et al., 2002), principalmente devido à conversão destas áreas naturais para áreas agrícolas e urbanas (Tilman et al., 2011). Atualmente, cerca de 50\% das florestas tropicais e subtropicais já se encontram totalmente convertidas (Sanderson et al., 2002; Hoekstra et al., 2005). Como as florestas tropicais são responsáveis por grande parte do estoque mundial de carbono terrestre (Falkowski et al., 2000; Vieira et al., 2008), estas mudanças na composição e estrutura de paisagens tropicais têm sido apontadas como uma das principais causas do aumento da concentração de gás carbônico na atmosfera, e por consequência, como um dos principais vetores das mudanças climáticas globais (IPCC, 2014). Além disso, essas transformações levam à perda da biodiversidade e de suas funções e serviços, reduzindo a disponibilidade de água, aumentando os riscos de erosão e perda de solo, entre outros efeitos adversos (Brown \& Lugo, 1990; MEA, 2005; Grimm et al., 2008; Butchart et al., 2010).

A provisão de serviços ecossistêmicos, definidas aqui como as "contribuições diretas e indiretas dos ecossistemas ao bem-estar humano" (TEEB, 2010), pode depender de como a composição e o arranjo espacial na paisagem afetam as espécies responsáveis pela provisão do serviço, principalmente em paisagens heterogêneas. O estoque de carbono, por exemplo, é significativamente reduzido em áreas de bordas florestais, devido a mudanças na composição de espécies e aumento da mortalidade de árvores nestas áreas (Laurance et al., 1997; D’Angelo 
et al., 2004). Por conseguinte, paisagens florestais com configuração muito fragmentada, que apresentam maior extensão de borda, tenderão a estocar menos carbono do que paisagens com a mesma cobertura florestal, porém onde os fragmentos são maiores e mais compactos (Pütz et al., 2011).

De uma forma geral, a estrutura da paisagem influencia processos ecológicos e, por sua vez, influenciam direta ou indiretamente os serviços ecossistêmicos (chamados de serviços da paisagem por alguns autores; Hermann et al., 2011; Willemen et al., 2012). Além de cobertura e conectividade, alguns outros aspectos da estrutura da paisagem têm sido propostos como mecanismos de regulação de serviços ecossistêmicos, em particular a heterogeneidade e a extensão de bordas. Em paisagens altamente fragmentadas, cujos fragmentos são pequenos, a influência combinada de bordas pode desencadear alterações ecológicas mais intensas do que seria esperado pelo efeito de apenas uma borda (Ries et al., 2004).

O estudo sobre quais são os mecanismos que regulam os serviços ecossistêmicos em mosaicos heterogêneos de áreas produtivas e de conservação, aliando o entendimento dos mecanismos de regulação local com aqueles associados à estrutura da paisagem para uma adequada extrapolação dos dados em escalas mais amplas, possui ainda muitas lacunas de conhecimento. $\mathrm{O}$ estoque de carbono se insere nesta questão, podendo variar muito em paisagens antropizadas e essa variação pode ocorrer por efeitos em diferentes escalas espaciais e temporais. Fatores abióticos, como a posição geográfica, atuam sobre o acúmulo de carbono em escala regional, enquanto pertubações humanas 
influenciam diretamente o estoque de carbono em escala local. Entre estas duas escalas espaciais, os efeitos da dinâmica da paisagem, por meio da fragmentação e desmatamento, também atuam sobre o manutenção do carbono em paisagens antropizadas. No entanto, a importância relativa da interação entre esses fatores é mal compreendida, apesar da relevância deste conhecimento para uma melhor compreensão do estoque de carbono e, assim, para uma melhor gestão das nossas paisagens para enfrentar as mudanças climáticas.

As florestas secundárias tropicais podem fornecer bens e serviços dos ecossistemas similares aos das florestas primárias, tais como proteção de bacias hidrográficas, controle de erosão, estabilização do clima regional, madeira e habitat (Brown \& Lugo, 1990; Guariguata \& Ostertag, 2001; Naughton-Treves \& Chapman, 2002). Os fatores que impactam a sucessão florestal nos estágios iniciais podem alterar fortemente o acúmulo de carbono pela vegetação (Chazdon et al., 2007). Quando a regeneração florestal é comprometida pela falta de fontes de vegetação e de propágulos residuais (Chazdon et al., 2007), ou quando há a compactação do solo por pastoreio e extrativismo de madeira, ou ainda desvio ou retardamento do processo sucessional por espécies exóticas (Hjerpe et al., 2001; Chinea, 2002; Fine, 2002; Zarin et al., 2005), tanto a sucessão quanto o estoque de carbono são negativamente influenciados.

A fim de contribuir nesse sentido, o presente estudo explora como as diferentes condições locais e da paisagem contribuem para o estoque de carbono. Para tanto, foi estudado como o estoque de carbono de uma floresta tropical varia com a idade da floresta, perturbação humana, topografia (declividade e altitude) e 
o contexto da paisagem (cobertura florestal e distância da borda da floresta). Espera-se mais provável observar valores mais altos de estoque de carbono em florestas mais antigas, menos perturbadas, situadas em altitudes mais elevadas e em encostas, rodeadas por uma paisagem com mais floresta e mais distantes das bordas da floresta. Para testar essas relações, avaliou-se a estrutura da floresta, distúrbios humanos e biomassa acima do solo (convertido para o estoque de carbono) em 27 locais de floresta secundária em paisagens antropizadas da Floresta Atlântica brasileira.

Devido à sua longa história de desmatamento e fragmentação, a Mata Atlântica brasileira é um cenário ideal para aprimorar a compreensão sobre os fatores que modulam os estoques de carbono em florestas tropicais (Metzger, 2009; Tabarelli et al., 2010). Hoje em dia, esta floresta está reduzida a cerca de 11-16\% de sua distribuição original (150 milhões de ha; Figura 1), com a maior parte dos fragmentos florestais remanescentes sendo reduzida a pequenos fragmentos, com menos de 50 ha (Ribeiro et al., 2009), e 91\% de sua área como borda de floresta (Pütz et al., 2011).

A Mata Atlântica ainda sofre com a expansão de diversos cultivos, como a cana-de-açúcar e o eucalipto, além da expansão das áreas urbanas e da ampla ocupação por áreas de pastagem (Ribeiro et al., 2011). O último relatório técnico da SOS Mata Atlântica (2014) apresenta um aumento de $9 \%$ na taxa de desmatamento no último ano (2012-2013) em relação ao ano anterior (20112012). Minas Gerais se encontra no topo da lista de estados com maior área desmatada: 10.572 ha de área desmatada no período de 2012 a 2013. Atualmente, 
cerca de 120 milhões de pessoas vivem na área original da Mata Atlântica, boa parte em áreas urbanas de grande porte (Tabarelli et al., 2010).

A região de estudo, o Sistema Cantareira $\left(23^{\circ} 02^{\prime} 01.31^{\prime}\right.$ S e $46^{\circ} 18^{\prime} 30.33$ 'O; 800-1600 m), está situada no sudeste do Brasil. Esta região é particularmente interessante para esse estudo, pois abriga uma área serrana rica em mananciais que abastecem cerca de $50 \%$ da região metropolitana de São Paulo, e é ao mesmo tempo uma área considerada de alta prioridade para conservação da biodiversidade pelo programa BIOTA/FAPESP (Rodrigues et al., 2008), porém com fortes pressões antrópicas. As paisagens desta região são muito heterogêneas, predominantemente ocupadas por áreas antrópicas $(69,4 \%)$, sendo que a maior parte são pastagens e eucaliptais (Whately \& Cunha, 2006), geralmente em pequenas propriedades. Da vegetação nativa restam cerca de $20 \%$, em diferentes estádios de sucessão e perturbação. 


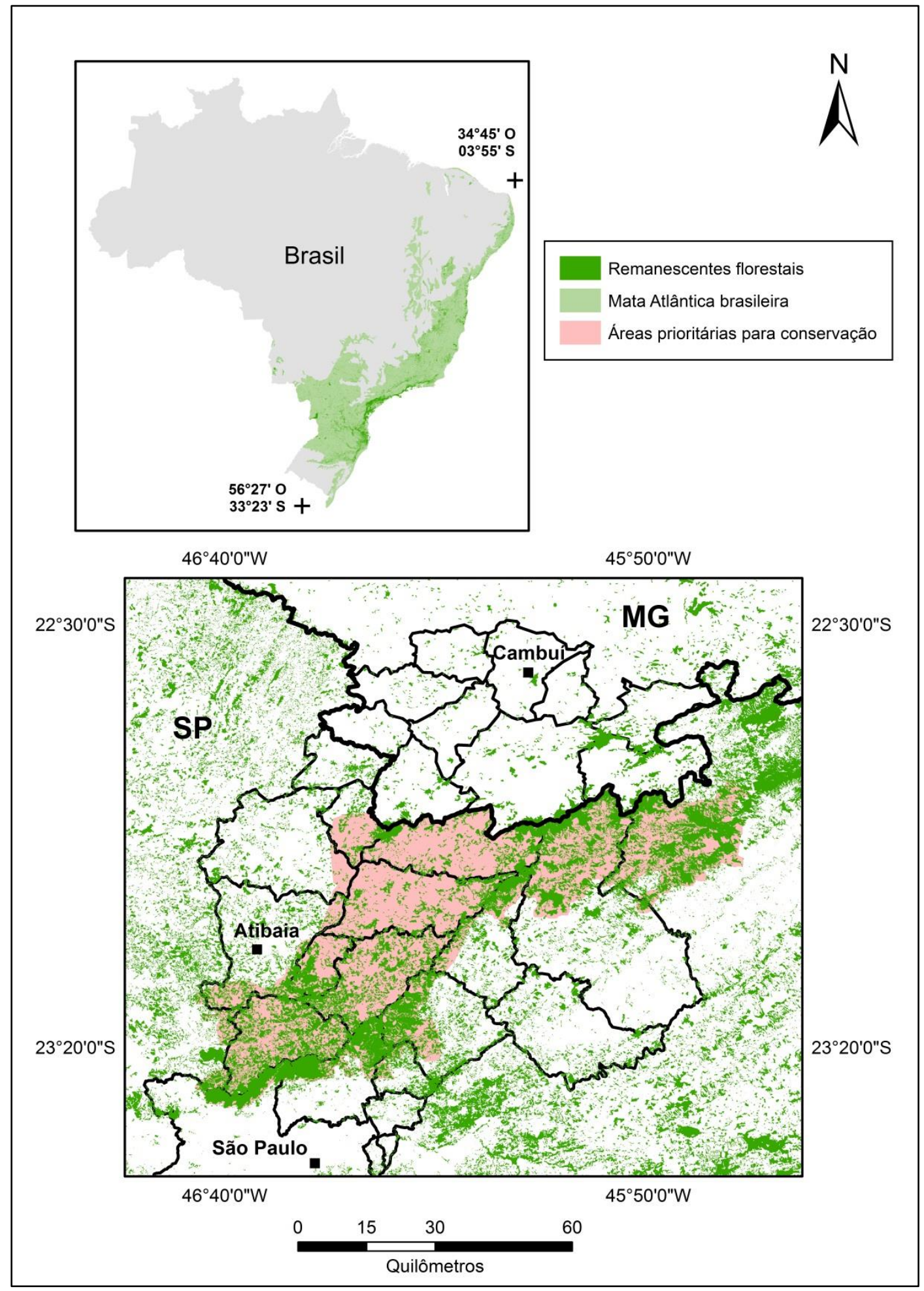

Figura 1 Distribuição dos remanescentes florestais da Mata Atlântica (SOS Mata Atlântica \& INPE, 2008) no Brasil e na região de estudo. As áreas prioritárias para conservação foram definidas pelo Projeto de Conservação e Utilização Sustentável da Diversidade Biológica Brasileira - PROBIO/MMA (2007). 


\title{
Capítulo único
}

\section{"High variability and low carbon stocks of tropical forest in human dominated landscapes"}

\begin{abstract}
Deforestation and fragmentation resulting from the expansion of human activities in tropical forest landscapes promote changes in landscape structure, usually with loss of mature forests for agriculture or pasture, partially offset regionally with the regeneration of young secondary forests. This process generates heterogeneous landscapes with secondary forests in different stages of succession and disturbance. The stock of carbon in these forests can thus vary greatly and this variation may occur at different spatial scales. This study aimed to understand how the different local and landscape conditions contribute to carbon stock. The study was performed in secondary Atlantic Forest fragments in Cantareira System (southeastern Brazil). The above-ground biomass (AGB) was estimated by forest inventory data and allometric biomass models. In order to test how the biomass of a tropical forest varies in disturbed landscapes, generalized linear models (GLM, Gaussian distribution) were constructed with four groups of variables: forest age; human disturbances; topography (terrain slope and elevation); and landscape structure. We constructed simple and compound, with and without interaction, models beyond to the null model. The most plausible model was selected by Akaike criterion corrected for small samples (AICc). On a more local scale, the variation of AGB according to the distance to the edge was analyzed. AGB varied widely among study sites and this was partly explained by the explanatory variables, since data suited better to all models and selected variables than the null model. The most surprising result was the low overall

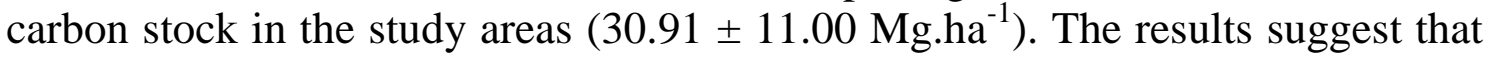
this pattern is mainly related to edge effects and the influence of factors directly driven by human occupation (e.g. more disturbed forests, landscapes with low forest cover and high relative occurrence of younger forests). The results also indicate that this condition of high disturbance abiotic factors, such as the topographical location, may have less importance than would be expected from previous studies. Low carbon stocks and high spatial variability indicate the need to incorporate in carbon stock estimates a finer spatial scale for climate mitigation and maintenance of ecosystem services programs in fragmented landscapes.
\end{abstract}

Keywords: Atlantic Forest, Above-ground biomass, Fragmented landscapes, Ecosystem services.

O capítulo único foi redigido em inglês sob o formato de artigo, seguindo os critérios do periódico Forest Ecology and Management. 


\section{Introduction}

Tropical forest landscapes are being transformed rapidly for the expansion of human activities, with deforestation rates reaching $0.3 \%$ annually (Asner et al., 2009). On the other hand, some tropical regions are also characterized by high rates of forest regeneration, leading to a forest transition process. In those cases, the loss of old growth forests to agriculture or pasture is compensated regionally with the regeneration of young secondary forests in abandoned lands (Ferraz et al., 2014). This process generates heterogeneous landscapes, creating secondary forests with different levels and histories of disturbance, which are continuously changing in structure and species composition (e.g., WilliamsLinera et al., 1998; Laurance et al., 2002; Galindo-Leal \& Gusmão-Câmara, 2003).

In human modified landscapes, secondary forests are of particular significance, first because they are becoming more dominant than old growth forests in the tropics due to the increasing anthropogenic pressures (Brown \& Lugo, 1990; Houghton, 1994; FAO, 2014; Thomlinson et al., 1996; Wright, 2005). Furthermore, secondary forests can provide important ecosystem goods and services, partially replacing the role of primary forests such as watershed protection, erosion control, regional climate stabilization, wood and non-timber products, and habitat for biodiversity (Brown \& Lugo, 1990; Guariguata \& Ostertag, 2001; Naughton-Treves \& Chapman, 2002). Particularly, secondary forests are an important stock of terrestrial carbon and thus can have profound impacts on the global carbon cycle (Houghton, 2013). Consequently, the 
recovery of secondary forests is nowadays studied, both to understand how different disturbance histories affect carbon stock and also to comprehend the implications of regeneration for carbon stock accumulation and climate change (Clark et al., 2001).

In tropical fragmented regions, landscape structure may have large implications on forest loss and regeneration, and thus can impact the dynamic of carbon stock. Specifically, isolated trees in pastures, as well as the amount of forest coverage in the surrounding landscape, may improve local regeneration by attracting seed-dispersing frugivores and facilitating recruitment conditions and seedling establishment (Guevara et al., 1992; Guevara \& Laborde, 1993; Galindo-Gonzalez et al., 2000; Slocum \& Horvitz, 2000; Slocum, 2001; Guevara \& Laborde, 2004). In addition, open habitats, usually crops or pasturelands introduced by humans, affect forest edges. Compared to the forest interior, those areas receive more insolation, are usually hotter and drier, and are more exposed to wind effects (Laurance et al., 2011). As a consequence, tree species composition is strongly affected. In particular, these open habitats have higher mortality of trees (Laurance et al., 1997; D'Angelo et al., 2004) and increased dominance of initial successional species (Laurance et al., 2011), resulting thus in lower carbon stock (Laurance et al., 2001). Furthermore, in highly fragmented landscapes, the combined influence of adjacent edges can provoke more intense ecological changes than would be expected from the effect of a single edge (Ries et al., 2004). Therefore, it is expected that the greater the amount of forest in the 
landscape and the less fragmented is the forest, the higher will be the carbon stock.

Besides the landscape effects, the accumulation of carbon can also be influenced by local factors. Different abiotic conditions, generally related to geographical relief, soil and climate, can alter forest regrowth as well as the distribution of big trees (Castilho et al., 2006), and thus can modulate carbon accumulation. The history of human disturbance, which affects the vegetation structure, can also contribute to explain changes in carbon stocks (Brown \& Lugo, 1990). The interaction of all those factors is also expected. Topography, for example, may act as a limiting factor for human access. As a result, forests in high elevations or with higher slopes are expected to be less degraded due to the difficulty of human access. This pattern has been observed in the Brazilian Atlantic forest (Vieira et al., 2011).

Carbon stock can thus vary widely in human dominated landscapes and such variation may occur by effects on different spatial and temporal scales. Despite the relevance of this knowledge for a better understanding of the dynamics of carbon stock, and thus for better management of our landscapes to face climate change, the relative importance and the interaction among those factors are poorly understood. In order to contribute to this cause, we studied how different local and landscape conditions contribute to carbon stock. More specifically, we tested how carbon stock of a tropical forest varies with forest age, human disturbance, topography (slope and elevation), landscape context (forest cover), and distance to forest edge. We expect to observe higher levels of 
carbon stock as forests are older, less disturbed, situated at higher elevations, farther from forest edges, and are surrounded by a landscape with more forest. To test those relationships, we assessed forest structure, human disturbances, and aboveground biomass (converted to carbon stock) varying in 27 sites of secondary forest in human-dominated landscapes from the Brazilian Atlantic forest. Due to its long history of deforestation and fragmentation, the Brazilian Atlantic forest is an ideal scenario to improve our understanding on the factors that modulate carbon stocks in tropical forests (Metzger, 2009; Tabarelli et al., 2010).

\section{Materials and methods}

\subsection{Study site and sampling design}

The Brazilian Atlantic forest is a highly diverse and endangered tropical forest that experienced unprecedented levels of habitat loss and other human disturbances since the 16th century (Dean, 1997; Cincotta et al., 2000). Nowadays, this forest is reduced to ca. $11-16 \%$ of its original distribution (150 millions ha), with most of the remaining forest patches being reduced to small fragments, with < 50 ha (Ribeiro et al., 2009), and 91\% of its area as forest edge (Pütz et al., 2011). Annual deforestation rates are around $0.5 \%$ for the whole Atlantic Forest (220 $\mathrm{km}^{2}$ year $^{-1}$; Soares-Filho et al., 2014), but may reach up to 2.9\% around São Paulo metropolitan area (Teixeira et al., 2009).

The study region is situated in Southeast Brazil encompassing a wide mountain ridge region responsible for more than $50 \%$ of the water supply of the city of São Paulo (Cantareira System, Figure 1). This region is not only relevant 
for water supply, but also for biodiversity conservation. It includes an important ecological corridor which was considered of high priority for biodiversity conservation at the state level (Rodrigues et al., 2008; Joly et al., 2010). Landscapes of the Cantareira system are very heterogeneous, comprising different land uses, mostly pasture areas in small properties and reforestation, especially with Eucalyptus spp. Native Atlantic Forest vegetation, in different successional stages and submitted to different levels of disturbance, represent only $21 \%$ of the studied region (Whately \& Cunha 2006). The region is also affected by an intermittent population that has vacation homes, due to its proximity to the capital of São Paulo State.

For site selection, we considered initially two factors, the elevation and the forest successional stage (Figure 1), which should be related with the other factors being tested. We expect that forests in higher elevation and in a more advanced successional stage will be older, will have less human disturbance, will be less affected by edge effects, and will be situated in landscapes with higher forest cover. We divided the Cantareira system into three elevation classes (800$1000 \mathrm{~m}, 1000-1200 \mathrm{~m}$, and above $1200 \mathrm{~m}$ elevation), in order to have approximately the same area of native vegetation in each class. We then considered three a priori successional stages (young, intermediate, and advanced), classified by an automatic supervised classification performed on SPOT images (2007), using the Feature Analyst. By combining elevation and successional classes, we obtained 9 sampling categories. For each category we choose randomly 3 replicates, resulting in 27 sites (Figure 1), distributed in 
patches of native montane Atlantic Forest vegetation (Veloso et al., 2012), with an average area between 1-6 ha.

\subsection{Inventory protocol}

We conducted the forest inventory from October 2012 to April 2013. Each sampling site consisted of two transects (100 meters long and 5 meters wide) parallel to each other and $10 \mathrm{~m}$ from each other. Transects were set perpendicularly to the forest edge, beginning 30 meters from the edge. In both transects, at the first 20 meters we measured all individuals with diameter at breast height $(\mathrm{DBH})$ higher than $4.8 \mathrm{~cm}$. In the remaining 80 meters, only individuals with $\mathrm{DBH}$ higher than $10 \mathrm{~cm}$ were measured. In short, we sampled 0.02 ha of individuals with more than $4.8 \mathrm{~cm} \mathrm{DBH}$ and 0.1 ha with more than 10 $\mathrm{cm}$ DBH for each sampled site. The diameters were measured at $1.3 \mathrm{~m}$ height $(\mathrm{DBH})$ of all live stems, including trees, palms, tree ferns, lianas, and standing dead trees and palms. The tree height was estimated with a telemeter.

\subsection{Allometric equations to estimate aboveground biomass (AGB)}

Eight different life forms were identified: trees, palms, tree ferns, lianas, standing dead trees and palms, and three not common species in moist forests Eucalyptus grandis, Pinus taeda, and Araucaria angustifolia (the latter being the only native species). We chose to keep all life forms in the inventory because they are all characteristic of secondary forests in the region.

We applied a secondary-growth Atlantic forest allometric model developed by Burger \& Delitti (2008) to estimate the Aboveground Biomass 
(AGB) for lives trees with $4.8 \mathrm{~cm} \mathrm{DBH}$. For palms, tree ferns, and lianas, we applied allometric equations developed in Brazilian tropical forests. For standing dead trees and palms, we calculated the volume of each cylindrical individual multiplying the density according to four decay classes developed by Keller et al. (2004). For the three not common species in moist forests AGB, we applied the allometric equations developed for forestry in the same study area (Table 1).

We summed and extrapolated the data to obtain the Aboveground Biomass (AGB) per hectare for each study site.

\subsection{Explanatory variables}

In order to analyze which factors influence the AGB observed along most of secondary-growth Atlantic Forest, we considered four local variables (age, terrain slope, elevation, and human disturbance) and two landscape variables (forest cover and distance to the edge).

Forest age was estimated based on aerial photographic surveys conducted by the Brazilian army in 1972 and images captured by LANDSAT 5 during the year of 1993. Forests were classified into three classes: over 40 years (present in photographs from 1972), between 20 and 40 years (present in 1972 photographs and in satellite images of 1993) and less than 20 years (absent in both records).

The elevation and terrain slope were obtained through topographic maps with 1:50,000 resolution and elevation of 20 meters provided by the Brazilian Institute of Geography and Statistics (IBGE).

The degree of human disturbance was evaluated with field data. We considered main disturbance types observed at the studied sites (such as presence 
of invasive species, logging, trails, livestock access, waste disposal, and road edge width), and combined the level of disturbances observed around the transects (ranked from 1 to 5) and the spatial range occupied by this disturbance (also ranked from 1 to 5) in a unique index by multiplying these two values. We obtained thus a human disturbance index per disturbance type. In case of more than one type of disturbance per site, the larger product of disturbance by spatial range was considered.

The forest cover in the sampled transect was calculated with a buffer of 1 $\mathrm{km}$, centered in the transect. We tested other landscape extents $(500 \mathrm{~m}, 2,4$ and $10 \mathrm{~km}$ ) and concluded that forest cover was highly correlated across spatial scales. To avoid higher overlap among sampling sites (which may be less than 2 $\mathrm{km}$ apart from each other), we opted for the $1 \mathrm{~km}$ buffer.

To test the effect of distance from the edge, sampling transects were divided in 5 blocks of $20 \mathrm{~m}(30-50 \mathrm{~m}, 50-70 \mathrm{~m}, 70-90 \mathrm{~m}, 90-110 \mathrm{~m}, 110-130 \mathrm{~m}$ from the closest forest edge). For this analysis, only individuals with DBH higher than $10 \mathrm{~cm}$ were considered, and the value for each block was the sum of the two transects from each site.

\subsection{Statistical analysis}

To quantify and model the relationships between AGB and the other explanatory variables, we used Gaussian distributions through generalized linear models (GLMs). The AGB found in each sampled site was used as the response variable. We built simple models in order to evaluate the individual effects of each explanatory variable (age, forest cover, terrain slope, elevation and human 
disturbance), as well as composed models in order to evaluate the effects (with and without interaction) of two variables, considering all possible combinations. We did not test models with three or more explanatory variables, and included a null model of no effect of the variables on the AGB. Before building the model, we conducted an exploratory data analysis to select only those explanatory variables with a relatively low correlation (Pearson's $r<0.70$; Zuur et al., 2009).

Furthermore, to test whether variation in AGB is affected by some unknown geographical pattern, we created three null models, composed by the individual and combined effects of latitude and longitude.

We selected the most plausible model among the 29 tested by the corrected Akaike information criterion (AICc). The AICc is a selection criterion that penalizes models with many parameters with a correction for small sample sizes (Burnham \& Anderson, 2002). Small values of AIC represent the best fit, so the model with the lowest value $\Delta$ AICc was considered the most plausible and models with $\triangle \mathrm{AICc}<2$ were considered equivalent. The statistical analyzes were performed using the R environment (R Development Core Team, 2013).

Due to its particular way of measure (distance to the nearest forest edge), edge effects were not considered as a variable in model construction. The effect of edge proximity on AGB was thus tested separately by comparing blocks at different distance in each site with a paired two-sample $t$-test. Previously, normality test (Shapiro-Wilk) and variance of the blocks were performed. 


\section{Results}

\subsection{Above-ground biomass estimation}

The sampled sites presented a large variation of AGB. The total average AGB for the 27 sites equals $65.34 \pm 21.19 \mathrm{Mg} \mathrm{ha}^{-1}$. The AGB contribution of each DBH class also varied widely between sites and between age classes of vegetation (Figure 2). In general, the 5-10 cm class contribution is low on AGB. The largest contribution is from individuals with intermediate DBH $(10-40 \mathrm{~cm})$. A larger contribution of individuals with higher DBH $(>60 \mathrm{~cm})$ occurs essentially in forests with more than 40 years.

\subsection{Factors influencing $A G B$}

Tested variables showed a wide range of variation among sites (Figure 3) and did not show strong correlation among them $(r<0.40)$, allowing their use as explanatory variables for AGB. The highest observed correlation was between age and terrain slope $(\mathrm{p}<0.05, r=-0.40)$.

Five tested models were equally plausible (Table 2). The spatial null models (with latitude and longitude) were last in the ranking. Similarly, the null constant model showed to be the worst models indicating that the AGB is indeed influenced by the studied explanatory factors, at random. Among all, age was the most strongly explanatory variable (Table 3 ). Terrain slope, landscape forest cover, and human disturbance were also among the best explanatory variables, but always in addition to age. Elevation was the unique explanatory variable that was not included in these five best models. 
Sites with less than 20 years and sites with more than 20 years differed greatly in AGB (Figure 4). Sites of 20-40 years and over 40 years were not significantly different. Comparing the AGB values found in this study with the values for Atlantic Rain Forest, Southeast Brazil (Groeneveld et al., 2009), AGB found in Cantareira is low, but there is an increasing trend of AGB for more mature forests (over 60 years; Figure 4A). Individuals with $\mathrm{DBH}>40 \mathrm{~cm}$ have a substantial contribution to AGB (24\%) in older forests, particularly for forests over 40 years (Figure 4B).

There was also a clear tendency of AGB increase from the edge (30-50 m) to the interior (110-130 m from the edge; Figure 5). Consistently, the blocks closer to the edge were different from all other blocks $(\mathrm{p}<0.05)$. The more distant edge block (110-130 m) had AGB significantly higher from the middle block (70-90 $\mathrm{m})$.

Finally, the relationship of AGB with the other explanatory variables was not strong, generally with a high degree of variability (Figure 6). There was a slow (but not significant) tendency of AGB decrease with higher human disturbance and higher elevation, while AGB increased slightly with a higher forest cover in landscape. No tendency was observed with terrain slope.

\section{Discussion}

The AGB varied widely among study sites and this was partially explained by the explanatory variables since all of the models and variables selected were better than the null models. The most striking result was the low carbon stock in the study sites. The fragmented landscapes from Cantareira system presented a 
relative low carbon stock if compared with what was obtained previously in other tropical forest (e.g. in the Amazon) or even in other areas of the Atlantic forest (Table 4). The observed values were only 50-30\% of the stocks observed in other mature or less fragmented landscapes, but were closer to the observed on edge stands from other Atlantic forest regions (Table 4). Our sampling design, that emphasizes edge areas, and the heterogeneity of conditions where the Atlantic forest is located in this highly deforested and disturbed region around the city of São Paulo can explain, at least partially, this pattern.

One of the clearest patterns in this study was the decrease of carbon stock from the interior to the edge, showing that processes occurring at edges are affecting tree survival and the accumulation and retention of carbon. This pattern was previously observed in the Amazon (Laurance et al., 2011; Berenguer et al., 2014) and also in the Atlantic forest (Paula et al., 2011), and is commonly associated with higher tree mortality on forest edges (Laurance et al., 2000). In the Amazon, tree mortality occurs more intensively in the first $100 \mathrm{~m}$ of the forest (Ferreira \& Laurance, 1997). When considering higher tree mortality within this first $100 \mathrm{~m}$, Pütz et al. (2011) showed that fragments under 50 ha are the main contributors to the loss of carbon stock in the Atlantic forest. However, field data indicated that the edge effects are more noticeable up to $35 \mathrm{~m}$ from the edge In the Atlantic Forest (Rodrigues, 1998). Then, it would be expected that most of our transects are under some kind of edge effect with a more clear and significant effect in the first block, situated between $30-50 \mathrm{~m}$ from the edges. Those areas are also the ones where other negative impacts on carbon stock, 
related to selective logging or understory clearcuts, are accentuated due to the facilitated access (Alencar et al., 2006; Berenguer et al., 2014).

Beyond edge effects, other particular conditions of the studied landscapes can help explain the low carbon stock observed. Particularly, forests around São Paulo (one of the biggest cities in the world) were submitted in the last 50 years to a fast dynamic of deforestation and regeneration (Teixeira et al., 2009; Lira et al., 2012a), resulting in forest fragments relatively young (Lira et al., 2012b). Since younger forests stock less carbon than older forest (Ditt et al., 2010; Paula et al., 2011; Ngo et al., 2013), a relatively low carbon stock would be expected. Indeed, our results suggested that age was the best variable that explained carbon stocks. Carbon stocks increased particularly fast between 20-40 years, while stocks tended to stagnate in older forests (over 40 years). However, when comparing the AGB values found in this study with the values from the Atlantic Rain Forest, it is expected to see an increase in AGB in more mature forests, over 60 years or more (Groeneveld et al., 2009; Figure 4A). This result is in accordance with the time required for the structural recovery of Atlantic Forest, which is estimated in more than 40 years (Piotto et al., 2009). Therefore, forest fragments in the studied area are still accumulating carbon and it would be expected an increase of more $34 \mathrm{Mg}$.ha-1 in the next 20 years (Groeneveld et al., 2009).

Another relevant factor to explain the low carbon stock is the high level of forest disturbance, which is usually related with more densely populated areas (Sassen \& Sheil, 2013), as those around São Paulo. In these conditions, when 
forests are submitted to high levels of disturbances, such as selective logging or understory clearcuts, carbon stocks in forests can decrease without a change in forest area (Houghton et al., 2005; Berenguer et al., 2014). In our study sites, the lowest AGB was observed in an area that was submitted to an intense selective logging $\left(20 \mathrm{Mg} \cdot \mathrm{ha}^{-1}\right) 5$ years before, resulting in a biomass of only one third of the average value $\left(65.34 \mathrm{Mg} \cdot \mathrm{ha}^{-1}\right)$. The wide variation in the amount of AGB among the sampled plots can thus be partially explained by these local effects of human activities, which act in distinct and intense ways.

Additionally, the presence of forest surrounding the study sites can positively affect AGB. Beyond the positive contribution of nearby forest fragments to facilitate forest regeneration (Guevara et al., 1992; Guevara \& Laborde, 1993; Galindo-Gonzalez et al., 2000), more forested landscapes are also less densely populated and thus less affected by human disturbances, favoring the accumulation of carbon. In general, the average forest cover in the studied region was low ( 20\%), which should also contribute to a low level of carbon stock. The biomass loss is a consequence of the combination of deforestation and fragmentation of forests (Laurance et al., 1997). Besides carbon stock being smaller near forest edges, as seen previously, the magnitude of biomass loss will depend on the spatial pattern of deforestation, ultimately, determining the size and shape of forest fragments. This fact justifies low carbon stocks found in highly fragmented landscapes that we studied, distinguishing it from other values of carbon stock found in other more forested and less fragmented Atlantic forest areas. 
Finally, elevation and terrain slope, although reported as important variables determining carbon stock (Vieira et al., 2011), were the variables that less influenced carbon stock. The influence of these abiotic factors can be potentially masked in the studied landscapes, due to a stronger effect of factors directly related to human activities particularly near forest edges (Berenguer et al., 2014). This draws attention to the need of assessing field data related to human disturbance, since the effects of these activities in global carbon stocks are still poorly understood (Aguiar et al., 2012).

Another relevant pattern of the carbon stock in the studied sites was its high spatial variability, which should be related with the heterogeneity of the studied landscapes. Probably, this variability should also be observed in other landscapes submitted to a long process of deforestation and disturbance, as those of the Brazilian Atlantic forest. This pattern should contrast with those observed in areas that have been deforested more recently, as most of the Amazon, where carbon stock is more homogeneously distributed or at least should be less affected by historical human disturbances, edge effects and different landscape context created by human activities. Our results suggested that spatial distribution of carbon in human dominated-landscapes, with a long history of disturbance, is less related to abiotic factors (such as climate, soils and topographic conditions) than in more pristine or recently deforested landscapes. Therefore, higher emphasis should be devoted in understanding how human related factors (such as edge effects, forest cover, and local disturbance) shape the spatial distribution of carbon stocks in those landscapes with an old history of 
occupation and disturbance, which nowadays represent most of the tropical forest region (Gardner et al., 2010; Tabarelli et al., 2010).

Consequently, high AGB variability observed in those fragmented landscapes should be better incorporated in conservation policies, such as in Payment for Ecosystem Services (PES) or Reducing Emissions from Deforestation and Forest Degradation (REDD) programs, which usually assume a more homogeneous carbon stock. According to our results, differences in carbon stock can be huge in the same climatic and abiotic conditions, mainly due to human-driven factors. For example, comparing the carbon stock accumulated in sites with less than 20 years with those with more than 20 years, there is a difference of $32 \%$ in carbon stock. This difference can increase to $63 \%$ when considering forests older than 60 years (Groeneveld et al., 2009). More specifically, carbon stock measured in this study was closer to measurements observed in other Atlantic Forest regions, but generally only $30-50 \%$ to carbon stocks in less fragmented landscapes and older forests. It is clear, thus, that age, edge effects, and other landscape factors (e.g. forest cover) should be considered when estimating carbon stock and planning actions to mitigate climate change. In order to reduce atmospheric emissions, PES and REDD programs should promote actions to preserve less fragmented forests, avoiding edge effects when possible and encouraging the maintenance of more mature forests in landscapes with greater forest cover.

We need new monitoring tools and a multi-scalar approach in order to monitor and determine the spatial and temporal carbon flow dynamics 
considering changes in forest spatial arrangements (Laurance et al., 1997), the creation of forest edge areas (Numata et al., 2011), and accounting for human influences on carbon stock. At coarse scales, monitoring can be based on satellite imagery, using time series to verify forest age and Lidar images to access human disturbances and edge effects. However, when more precise data are necessary in a more specific spatial area, then it would be highly recommended to complement remote sensing data with field data to detect more precisely other local factors that influence carbon stock, such as human degradation.

\section{Conclusions}

Our study reveals a new (and unexpected) pattern of relatively low carbon stock and high variability in the spatial distribution of carbon stock in tropical forests of a human-dominated landscape. Results suggested that this pattern is mostly related to edge effects and to the influence of factors directly driven by human occupation (e.g. high local disturbance of more mature forest, regeneration of young forests, low forest cover), showing that in this condition abiotic factors (such as topographic location) can have a lower importance than would be expected by previous studies.

The high spatial variability in carbon stocks challenges the traditional approach of programs that aim to reduce greenhouse gas emissions and maintain ecosystem services. Those programs usually consider only average values of carbon accumulation, estimated essentially using abiotic proxies (e.g. climate and geographical relief parameters), which are then extrapolated for large spatial territories, ignoring the spatial arrangement of the remaining forest and the 
impact of human-related factors. To avoid those problems, we need better estimations of the effect of human-driven factors on carbon stocks, either by using remote sensing, field data or both. This more refined information of the spatial distribution of carbon stock according to how humans are shaping landscapes is crucial to improve programs of climate change mitigation in fragmented landscapes, which are becoming the dominant type of landscape in tropical regions. 


\section{Figures}

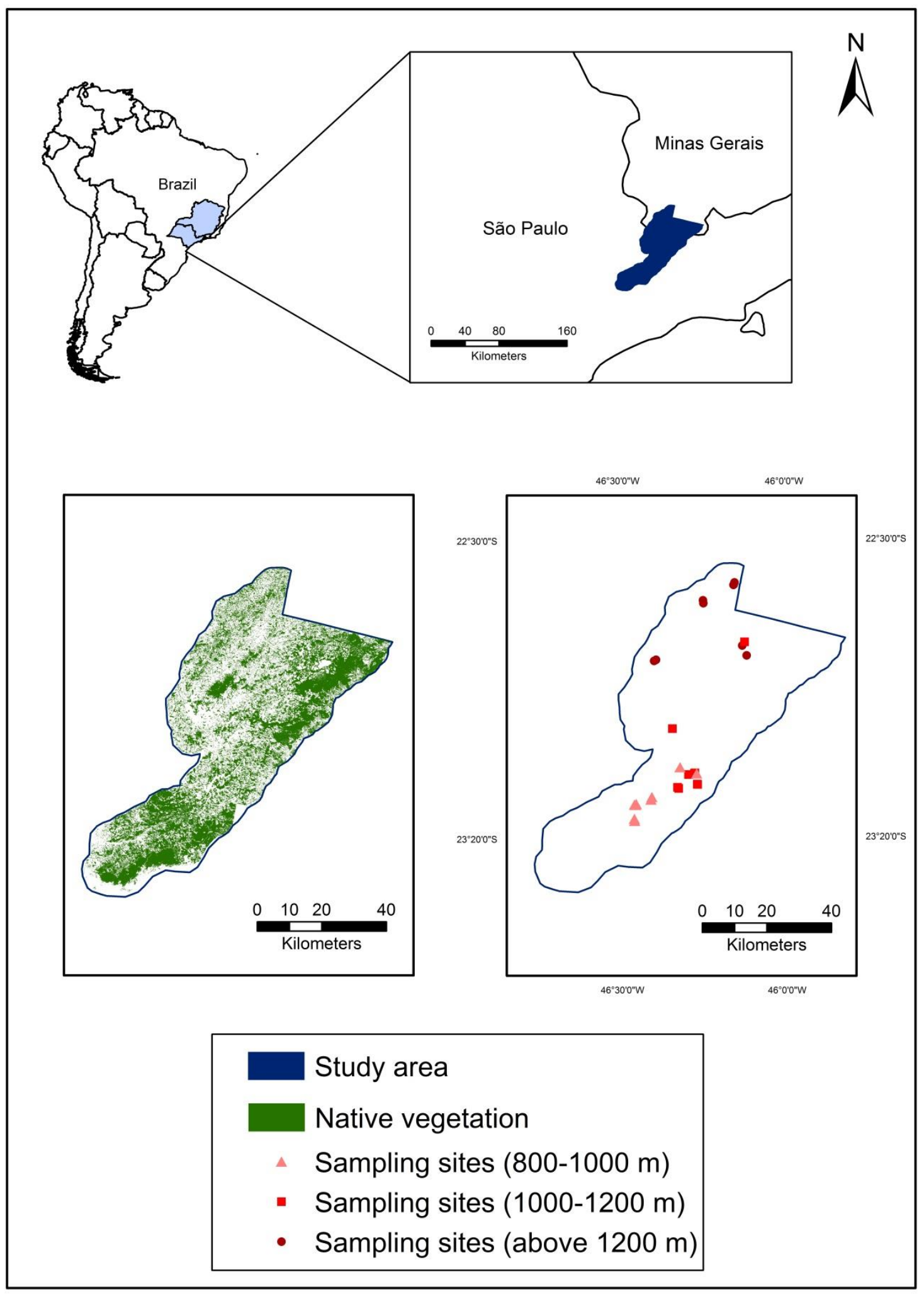

Figure 1

The study region (Cantareira System), between the states of São Paulo and Minas Gerais, Southeast Brazil. 


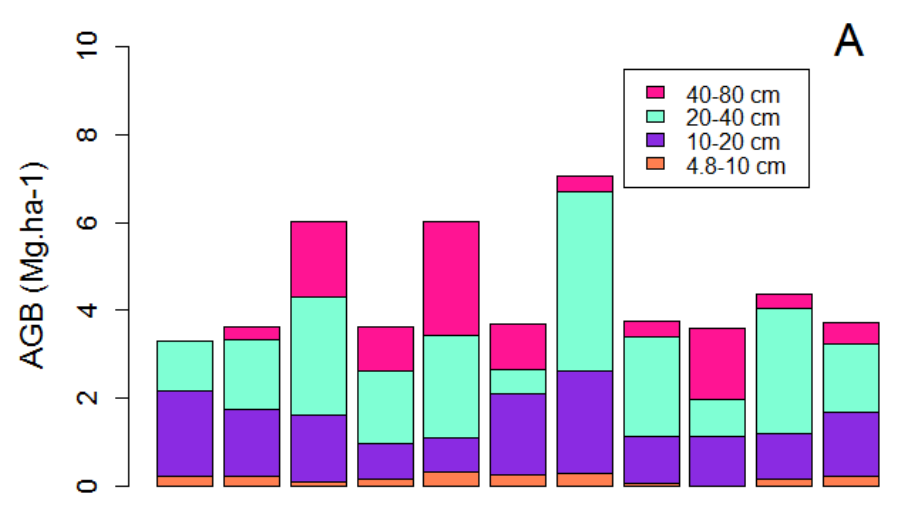

less than 20 years

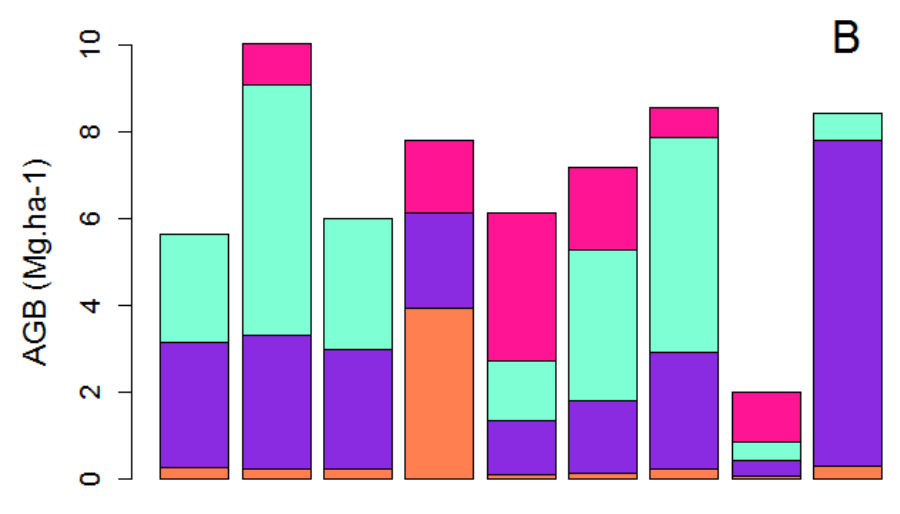

between 20 and 40 years

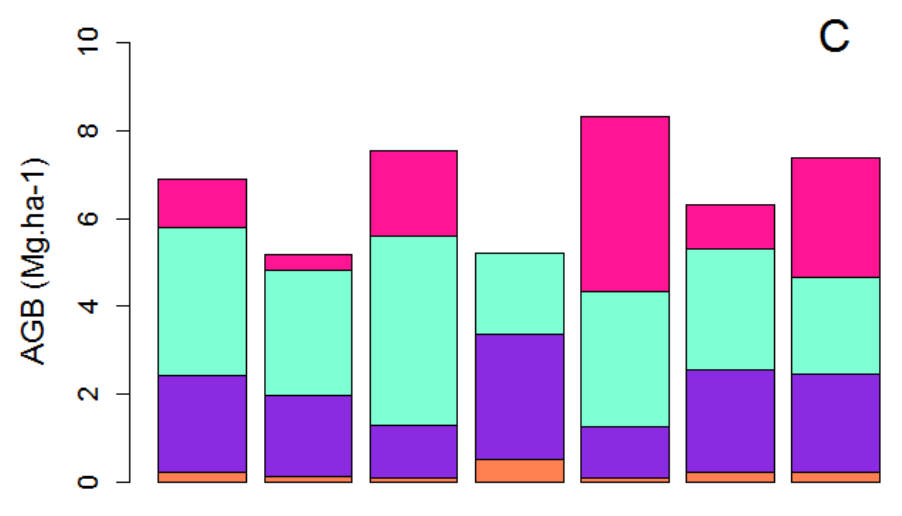

over 40 years

\section{Figure 2}

AGB at each sampled sites and the AGB contribution for each DBH class. A) Sites sampled vegetation with less than 20 years; B) Sites sampled with vegetation between 20 and 40 years old; C) Sites sampled with vegetation over 40 years 

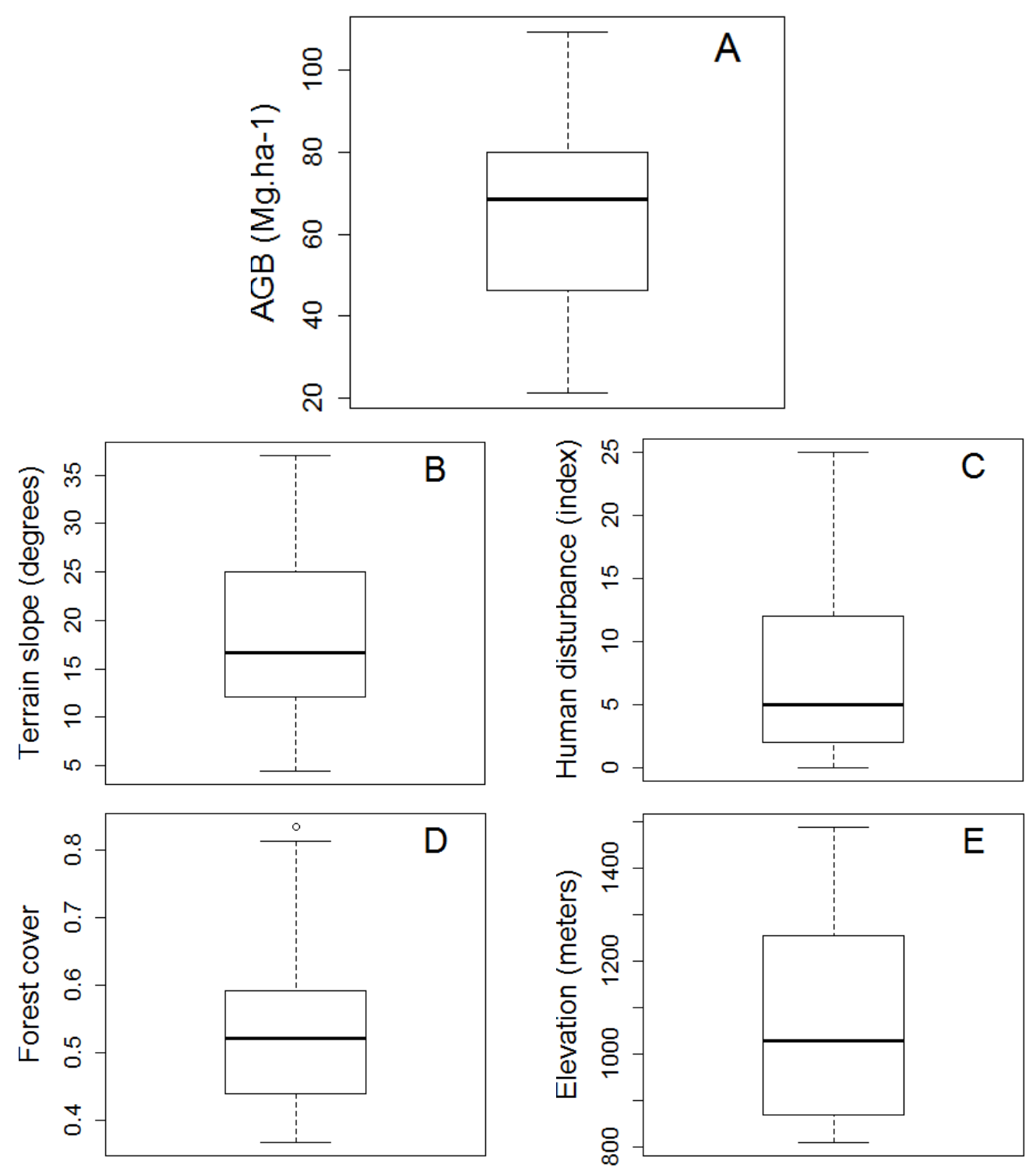

\section{Figure 3}

Range of values observed for the AGB and the explanatory variables among the 27 sites in the study region (Cantareira System). A thick middle line represents the median, the box represents the 1st and 3rd quartile, and "whiskers" represent the maximum and minimum values. Age was not shown here because it is a categorical variable. 

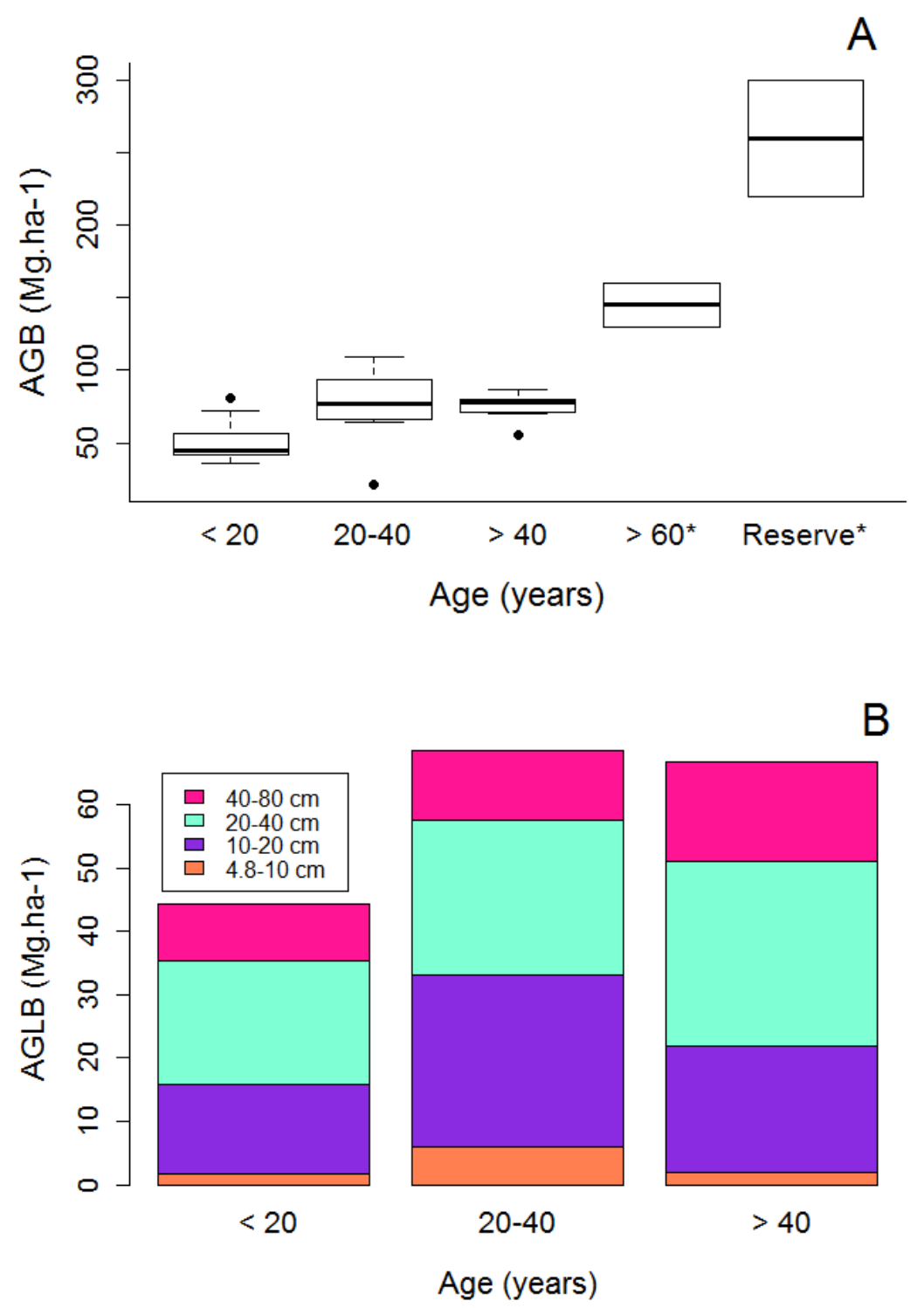

\section{Figure 4}

AGB by age class of vegetation. A) Boxplot of AGB, for the first three classes (less than 20 years, between 20 and 40 years and over 40 years). A thick middle line represents the median, the box represents the 1st and 3rd quartile, and "whiskers" represent the maximum and minimum values. For fourth and fifth age class (more than 60 years and Reserve) thick middle line represents the median and the box represents the range between the minimum and maximum values found; B) AGB at each sampled sites and the AGB Contribution for each DBH class.

* These values correspond to the results found by Groeneveld et al. (2009) in

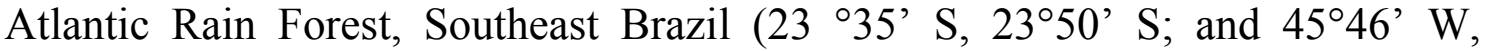
$\left.47^{\circ} 15^{\prime} \mathrm{W}\right)$. AGB values for more than 60 years was found in forest fragments of 2 ha more than $6 \mathrm{~km}$ from a large ( $10.000 \mathrm{ha})$ forest area. The "Reserve" refers to an old-growth forest area inside a 10.000 ha forest reserve. 


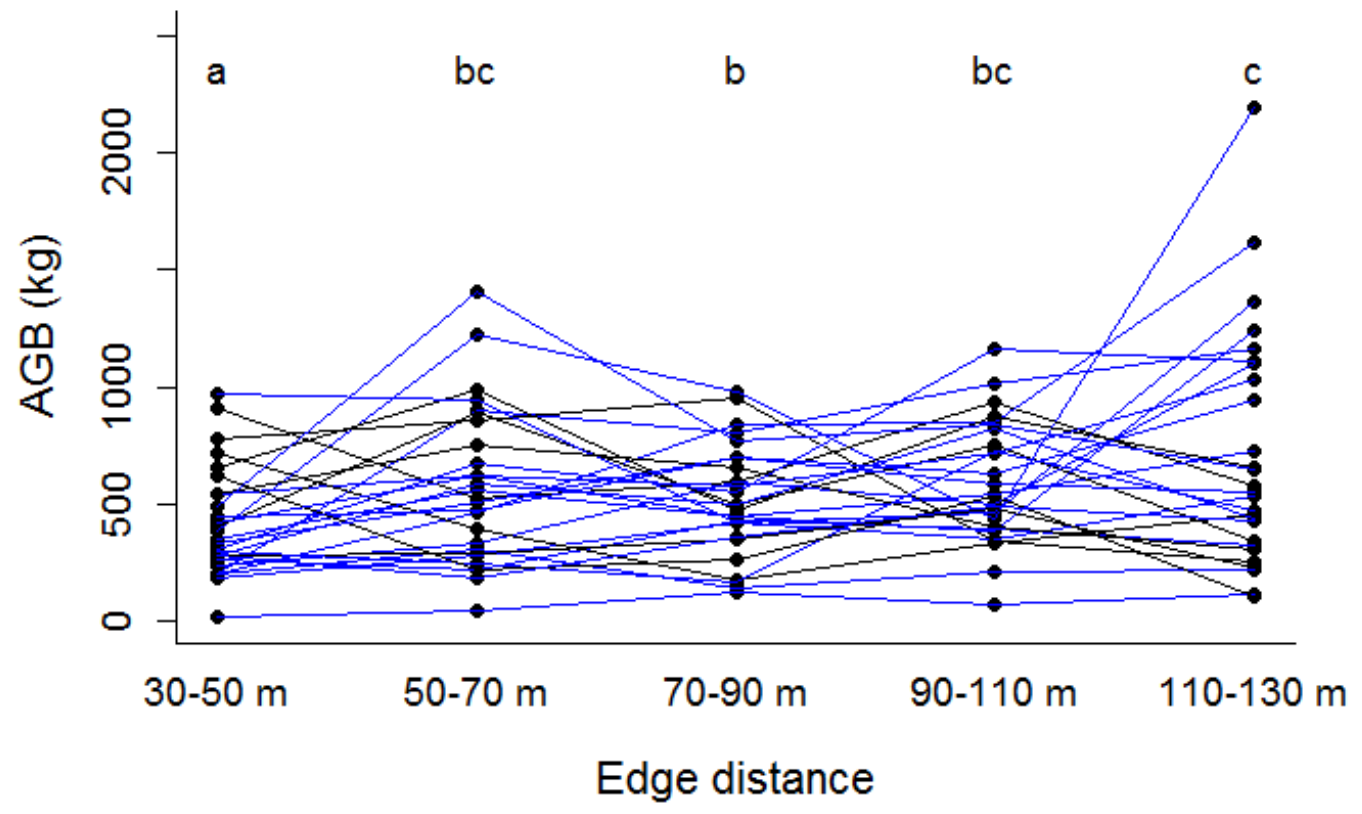

\section{Figure 5}

AGB along the sampled transect. The different letters indicate statistical difference (paired two-sample $t$-test). The blue lines indicate sites that the more distance edge block (110-130 m) has AGB higher from the less distance edge block (30-50 m). 


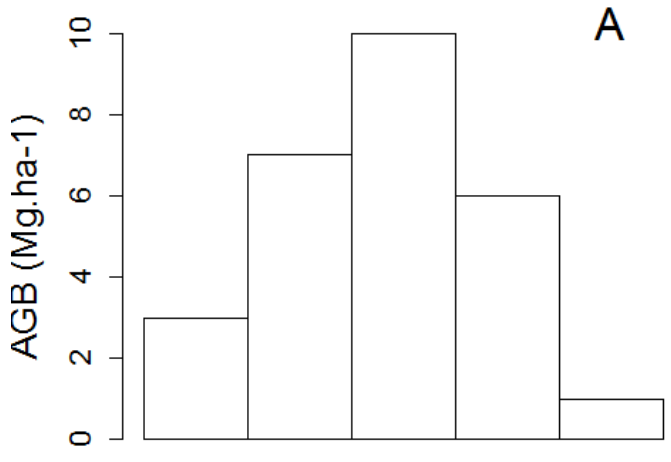

Sampled plots (n)

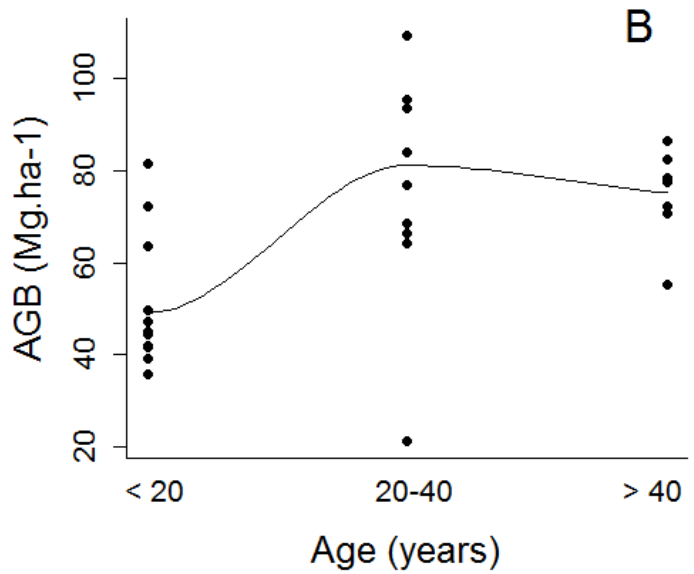

Figure 6

A) Histogram of AGB for the 27 sampled plots; B) AGB as a function of the age. 


\section{Tables}

\section{Table 1 - Allometric equations}

Allometric equations used to estimate stem AGB $(\mathrm{kg})$ at 27 sites sampled in native vegetation fragments (Atlantic Forest, Brazil). DBH: diameter at breast height $(\mathrm{cm}), \mathrm{H}$ : total height $(\mathrm{m})$.

\begin{tabular}{|c|c|c|}
\hline Life forms & Allometric equations & Source \\
\hline Trees & $\mathrm{AGB}=\exp \left(-3.676+0,951 *\left(\operatorname{Ln}\left(\mathrm{DBH}^{2}\right)^{*} \mathrm{H}\right)\right)$ & $\begin{array}{l}\text { Burger \& Delitti } \\
\quad(2008)\end{array}$ \\
\hline Palms & $\left.\mathrm{AGB}=\exp \left(0.9285^{*}\left(\operatorname{Ln}\left(\mathrm{DBH}^{2}\right)\right)+5.7236\right) * 1.050001\right) / 10^{\wedge} 3$ & $\begin{array}{l}\text { Hughes et al. } \\
\text { (1999) }\end{array}$ \\
\hline Tree ferns & $\mathrm{AGB}=-4266348 /\left(1-2792284 \exp -0.313677^{* \mathrm{H}}\right)$ & $\begin{array}{l}\text { Tiepolo et al. } \\
\quad \text { (2002) }\end{array}$ \\
\hline Lianas & $\mathrm{AGB}=\exp (-1.484+2.657 \operatorname{Ln}(\mathrm{DBH}))$ & $\begin{array}{l}\text { Schnitzer et al. } \\
\quad \text { (2006) }\end{array}$ \\
\hline Standing dead trees and palms (Decay class 1 ) & $\mathrm{AGB}=0.51 *\left(\left(\pi^{*}(\mathrm{DBH} / 200)^{2}\right) * \mathrm{H}\right)$ & \\
\hline Standing dead trees and palms (Decay class 2) & $\mathrm{AGB}=0.42 *\left(\left(\pi *(\mathrm{DBH} / 200)^{2}\right) * \mathrm{H}\right)$ & Keller et al. (2004) \\
\hline Standing dead trees and palms (Decay class 3) & $\mathrm{AGB}=0.36^{*}\left(\left(\pi^{*}(\mathrm{DBH} / 200)^{2}\right) * \mathrm{H}\right)$ & \\
\hline Standing dead trees and palms (Decay class 4 ) & $\mathrm{AGB}=0.30 *\left(\left(\pi *(\mathrm{DBH} / 200)^{2}\right) * \mathrm{H}\right)$ & \\
\hline Araucaria angustifolia & $\mathrm{AGB}=\exp (-2.09238+2.41141 * \operatorname{Ln}(\mathrm{DBH}))$ & $\begin{array}{l}\text { Schumacher et al. } \\
\qquad(2011)\end{array}$ \\
\hline Eucalyptus grandis & $\mathrm{AGB}=\exp (-4.833265+1.8284191 * \mathrm{LnDBH}+1.1724611 * \mathrm{LnH})$ & Soares et al. (2005) \\
\hline Pinus taeda & $\mathrm{AGB}=\exp \left(-9,98595+0,97741 *\left(\operatorname{Ln}\left(\mathrm{DBH}^{2} \mathrm{H}\right)\right)\right.$ & $\begin{array}{l}\text { Couto \& Vetorazzo } \\
\text { (1999) }\end{array}$ \\
\hline
\end{tabular}




\section{Table 2 - Best supported models}

Best supported models to explain variation in the above ground biomass (AGB) in the studied 27 sites (Cantareira system, Brazil). Considered explanatory variables: forest age (age), terrain slope, elevation, human disturbance and forest cover. Each model is described by the degrees of freedom (df), $\triangle \mathrm{AICc}$ and weight. The tilde $(\sim)$ means the function and the colon $(:)$ the interaction.

\begin{tabular}{lccc}
\hline \multicolumn{1}{c}{ Model } & df & $\Delta$ AICc & weight \\
\hline AGB $\sim$ age & 3 & 0.0 & 0.22590 \\
AGB $\sim$ age + terrain slope + age: terrain slope & 5 & 0.9 & 0.14673 \\
AGB $\sim$ age + forest cover & 4 & 1.3 & 0.11537 \\
AGB $\sim$ age + human disturbance & 4 & 1.4 & 0.11324 \\
AGB $\sim$ age + terrain slope & 4 & 1.7 & 0.09519 \\
AGB $\sim$ age + elevation & 4 & 2.1 & 0.07997 \\
\hline
\end{tabular}

Table 3 - Weight variable and variable explanation proportion of the explanatory variables tested

\begin{tabular}{lcc}
\hline \multicolumn{1}{c}{ Explanatory variable } & Weight variable & Variable explanation proportion \\
\hline age & 0.916 & $54 \%$ \\
terrain slope & 0.283 & $17 \%$ \\
forest cover & 0.216 & $13 \%$ \\
human disturbance & 0.173 & $10 \%$ \\
elevation & 0.117 & $7 \%$ \\
\hline
\end{tabular}




\section{Table 4 - Values of carbon stock obtained in different regions of the tropical forest}

Values of carbon stock obtained in different regions of the tropical forest. In order to compare our data with others studies, biomass data was converted in carbon stock, by multiplying AGB to carbon concentration of 47.4\% (Martinelli et al., 2000).

\begin{tabular}{|c|c|c|c|c|c|}
\hline Sampling & $\begin{array}{l}\text { Stage of forest } \\
\text { succession }\end{array}$ & Forest type & Country & $\begin{array}{l}\text { Carbon stock } \\
\text { (C Mg.ha-1) }\end{array}$ & Source \\
\hline $\begin{array}{c}\text { Edge transect } \\
\text { (gradient distance) }\end{array}$ & Young & $\begin{array}{l}\text { Montane moist forest, } \\
\text { Atlantic Forest }\end{array}$ & Brazil & $30.91 \pm 11.00$ & This study \\
\hline Edge stands & Mature (protected area) & $\begin{array}{l}\text { Lowland semi-deciduous } \\
\text { forest, } \\
\text { Atlantic Forest }\end{array}$ & Brazil & 42.1 & Paula et al. (2011) \\
\hline Fragment stands & Young (protected area) & $\begin{array}{l}\text { Lower Montane moist forest, } \\
\text { Atlantic Forest }\end{array}$ & Brazil & 45.12 & Groeneveld et al. (2009) \\
\hline- & Young & $\begin{array}{l}\text { Lower Montane moist forest, } \\
\text { tropical forest }\end{array}$ & $\begin{array}{l}\text { Puerto } \\
\text { Rico }\end{array}$ & 53.1 & $\begin{array}{l}\text { Marin-Spiotta et al. } \\
\qquad(2007)\end{array}$ \\
\hline Fragment stands & Old (protected area) & $\begin{array}{l}\text { Lower Montane moist forest, } \\
\text { Atlantic Forest }\end{array}$ & Brazil & 65.8 & Groeneveld et al. (2009) \\
\hline- & Young & $\begin{array}{l}\text { Montane moist forest, } \\
\text { Atlantic Forest }\end{array}$ & Brazil & 71.6 & Ditt et al. (2010) \\
\hline- & Old & $\begin{array}{l}\text { Lower Montane moist forest, } \\
\text { tropical forest }\end{array}$ & $\begin{array}{l}\text { Puerto } \\
\text { Rico }\end{array}$ & 103.9 & $\begin{array}{l}\text { Marin-Spiotta et al. } \\
\text { (2007) }\end{array}$ \\
\hline
\end{tabular}




\section{Table 4 - Values of carbon stock obtained in different regions of the tropical forest (cont.)}

Values of carbon stock obtained in different regions of the tropical forest. In order to compare our data with others studies, biomass data was converted in carbon stock, by multiplying AGB to carbon concentration of 47.4\% (Martinelli et al., 2000).

\begin{tabular}{|c|c|c|c|c|c|}
\hline Sampling & $\begin{array}{l}\text { Stage of forest } \\
\text { succession }\end{array}$ & Forest type & Country & $\begin{array}{l}\text { Carbon stock } \\
\text { (C Mg.ha-1) }\end{array}$ & Source \\
\hline- & Old (protected area) & $\begin{array}{l}\text { Lowland moist forest, } \\
\text { tropical Forest }\end{array}$ & Singapore & 104.12 & Ngo et al. (2013) \\
\hline- & Mature (protected area) & $\begin{array}{l}\text { Lowland moist forest, } \\
\text { tropical Forest }\end{array}$ & Singapore & 111.21 & Ngo et al. (2013) \\
\hline- & Old & $\begin{array}{l}\text { Montane moist forest, } \\
\text { Atlantic forest }\end{array}$ & Brazil & 113.43 & Ditt et al. (2010) \\
\hline Interior stands & Old (protected area) & $\begin{array}{l}\text { Lower Montane moist forest, } \\
\text { Atlantic Forest }\end{array}$ & Brazil & 117.5 & Groeneveld et al. (2009) \\
\hline Interior stands & Mature (protected area) & $\begin{array}{l}\text { Montane moist forest, } \\
\text { Atlantic Forest }\end{array}$ & Brazil & 124.52 & Alves et al. (2010) \\
\hline- & Mature (protected area) & $\begin{array}{l}\text { Lowland moist forest, } \\
\text { tropical forest }\end{array}$ & Panama & 133.19 & Chave et al. (2003) \\
\hline- & Mature (protected area) & Amazonian tropical forest & Brazil & 147.6 & Vieira et al. (2004) \\
\hline - & Mature (protected area) & $\begin{array}{l}\text { Central Amazonian, } \\
\text { tropical forest }\end{array}$ & Brazil & 188.5 & $\begin{array}{c}\text { Nascimento \& Laurance } \\
\text { (2002) }\end{array}$ \\
\hline
\end{tabular}




\section{Conclusões gerais}

As florestas tropicais em paisagens antropizadas estudadas aqui apresentaram um valor relativamente baixo de estoque de carbono, além da alta variabilidade na distribuição espacial deste estoque. Os resultados sugerem que este padrão está principalmente relacionado com efeitos de borda e à influência de fatores diretamente impulsionados pela ocupação humana (por exemplo, florestas mais perturbadas; paisagens com baixa cobertura florestal e com muitas florestas relativamente jovens), mostrando que nestas condições os fatores abióticos, como a localização topográfica, podem ter uma importância menor do que era esperado em estudos anteriores (Figura 2).

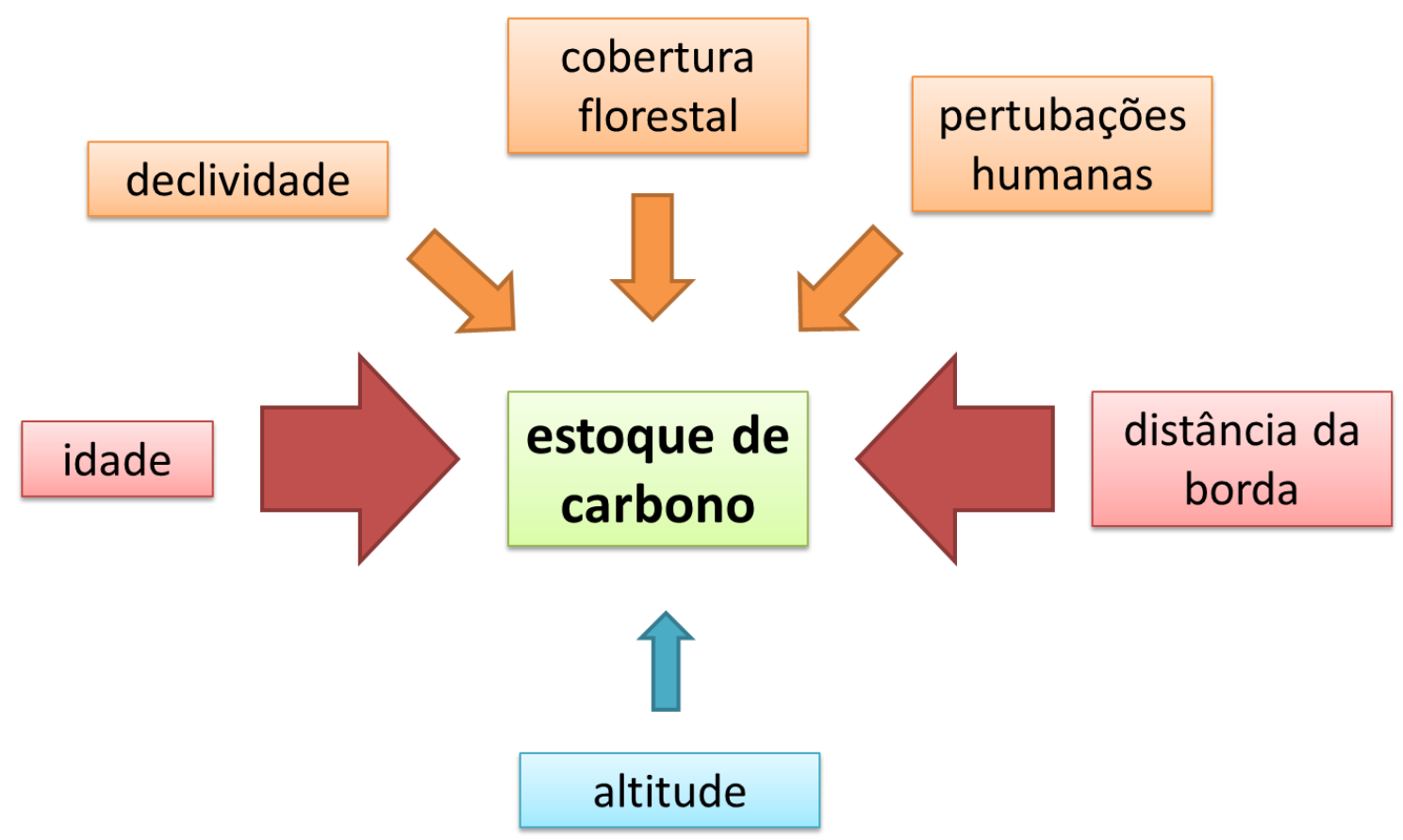

Figura 2 Peso das variáveis testadas (representado pelo tamanho das setas) sobre o estoque de carbono. A alta variabilidade espacial deve-se ao balanço entre estas variáveis, que corre de forma distinta sítio a sítio. 
A alta variabilidade espacial nos estoques de carbono desafia a abordagem tradicional de programas que visam reduzir as emissões de gases de efeito estufa e manter os serviços ecossistêmicos. Esses programas geralmente consideram apenas os valores médios de acúmulo de carbono, estimado essencialmente usando indicadores abióticos (e.g., parâmetros de clima e relevo), que são então extrapolados para grandes territórios espaciais, ignorando o arranjo espacial dos remanescentes florestais e o impacto de fatores relacionados ao homem. Para evitar esses problemas, precisamos de melhores estimativas do efeito de fatores humanos sobre os estoques de carbono.

O entendimento das variações nos estoques de carbono em relação a fatores ligados à idade das florestas, grau de perturbação humana, contexto abiótico (e.g. declividade e altitude) e de paisagem (cobertura florestal e distância da borda da floresta) é assim essencial para um melhor planejamento das paisagens dominadas pelo homem, de modo que elas mantenham níveis satisfatórios de serviço de estocagem de carbono. Esse conhecimento poderá contribuir, por exemplo, para a definição do extensões mínimas ou para demarcação de arranjos espaciais ideais de áreas de preservação de vegetação nativa.

Ademais, esse estudo pode contribuir para embasar políticas públicas que visem a manutenção de serviços ecossistêmicos, em particular através do Pagamento por Serviço Ambiental (PSA). Os serviços ambientais são definidos como as atividades humanas que contribuem para manter ou aumentar a provisão dos serviços ecossistêmicos (Chomitz et al., 1999). O PSA está atualmente na agenda das maiores ONGs (The Nature Conservancy - TNC, Conservation 
International - CI, World Wide Fund for Nature - WWF e SOS Mata Atlântica, em particular) e dos principais órgãos responsáveis pela elaboração e execução de políticas públicas em gestão ambiental no país. Ao fornecer bases científicas para programas de PSA, projetos, como os desenvolvidos nessa dissertação, propiciam uma avaliação mais efetiva do serviço prestado em diferentes contextos de paisagem, e subsidiam programas de monitoramento de PSA, auxiliando assim na avaliação da efetividade destes programas.

O presente trabalho contribui também com a maior efetividade de programas de mitigação de mudanças climáticas, como o REDD+ (Redução das Emissões por Desmatamento e Degradação Florestal). Esses programas vêm sendo propostos como estratégia de mitigação da mudança do clima através da redução compensada de emissões de carbono por desmatamento e degradação florestal. Esta redução ocorre por meio de iniciativas de conservação florestal, manejo sustentável e aumento dos estoques de carbono. O presente trabalho contribui neste sentido a medida que evidencia que a conservação de matas mais antigas e com menor área de borda é altamente relevante para o aumento do estoque de carbono em florestas. Desta forma, é importante evitar a compensação de áreas de florestas nativas mais antigas por áreas de florestas nativas mais novas e/ou com maior área de borda, visto que a perda de estoque de carbono é muito elevada nesta troca e de lenta recuperação (mais de 40 anos).

Em conclusão, a informação mais refinada da distribuição espacial do carbono, gerada por essa dissertação, é crucial para direcionar e aprimorar programas de Pagamento por serviço Ambiental e programas de mitigação de 
mudanças climáticas em paisagens fragmentadas, que estão se tornando o tipo dominante de paisagem em regiões tropicais. 


\section{Resumo}

O desmatamento e a fragmentação decorrentes da expansão das atividades humanas nas paisagens florestais tropicais promovem mudanças na estrutura da paisagem, em geral com perda de florestas antigas para a agricultura ou pastagem, parcialmente compensada regionalmente com a regeneração das florestas secundárias jovens. Tal processo gera paisagens heterogêneas, com florestas secundárias em diferentes estádios de sucessão e perturbação. O estoque de carbono nestas florestas pode, assim, variar muito e essa variação pode ocorrer em diferentes escalas espaciais. O presente estudo buscou entender como as diferentes condições locais e da paisagem contribuem para o estoque de carbono. $\mathrm{O}$ estudo foi realizado em florestas secundárias da Mata Atlântica, no Sistema Cantareira (região sudeste do Brasil). A biomassa acima do solo (BAS) foi estimada a partir de dados de inventário florestal e modelos alométricos de biomassa. A fim de testar como a biomassa de uma floresta tropical varia em paisagens antropizadas, foram construídos modelos lineares generalizados (GLM, distribuição Gaussiana) com quatro grupos de variáveis: idade da floresta; perturbações humanas; topografia (declividade e altitude); e estrutura da paisagem. Foram construídos modelos simples, compostos, com e sem interação, além do modelo nulo. O modelo mais plausível foi selecionado pelo critério de Akaike corrigido para pequenas amostras (AICc). Numa escala mais local, a variação da BAS em função da distância à borda foi analisada. A BAS variou amplamente entre os locais de estudo e isso foi parcialmente explicado pelas variáveis explanatórias, uma vez que todos os modelos e variáveis selecionadas foram melhores do que os modelos nulos. $\mathrm{O}$ resultado mais surpreendente foi $\mathrm{o}$ baixo estoque geral de carbono nas áreas de estudo $\left(30,91 \pm 11,00 \mathrm{Mg} \mathrm{ha}^{-1}\right)$. Os resultados sugerem que este padrão está principalmente relacionado com efeitos de borda e com a influência de fatores diretamente impulsionados pela ocupação humana (como, por exemplo, florestas mais perturbadas, paisagens com baixa cobertura florestal e ocorrência relativa alta de florestas mais jovens). Os resultados indicam ainda que nesta condição de alta perturbação, os fatores abióticos, tais como a localização topográfica, podem ter uma importância menor do que seria de esperar por estudos anteriores. Os baixos estoques de carbono e alta variabilidade espacial observada indicam a necessidade de se incorporar estimativas de carbono em escalas espaciais mais finas em programas de mitigação climática e de manutenção de serviços ecossistêmicos em paisagens fragmentadas.

Palavras-chave: Florestas tropicais, Biomassa acima do solo, Serviços ecossistêmicos 


\section{Referências bibliográficas}

Achard, F., Eva, H.D., Stibig, H.J., Mayaux, P., Gallego, J., Richards, T., Malingreau, J.P. 2002. Determination of deforestation rates of the world's humid tropical forests. Science 297, 999-1002.

Aguiar, A.P.D., Ometto, J.P., Nobre, C., Lapola, D.M., Almeida, C., Vieira, I.C., Soares, J.V., Alvala, R., Saatachi, S., Valeriano, D., Castilla-Rubio, J.C. 2012. Modeling the spatial and temporal heterogeneity of deforestation-driven carbon emissions: the INPE-EM framework applied to the Brazilian Amazon. Glob. Change Biol. 18, 3346-3366.

Alencar, A., Nepstad, D.C., Diaz, M., Vera, C. 2006. Forest understory fire in the Brazilian Amazon in ENSO and non-ENSO years: area burned and committed carbon emissions. Earth Interact. 10, 1-17.

Alves, L. F., Vieira, S.A., Scaranello, M.A., Camargo, P.B., Santos, F.A.M., Joly, C.A., Martinelli, L.A. 2010. Forest structure and live aboveground biomass variation along an elevational gradient of tropical Atlantic moist forest (Brazil). For. Ecol. Manage. 260, 679-691.

Asner, G.P., Rudel, T.K., Aide, T.M., Defries, R., Emerson, R. 2009. A contemporary assessment of change in humid tropical forests. Conserv. Biol. 23, 1386-1395.

Berenguer, E., Ferreira, J., Gardner, T.A., Aragão, L.E.O.C., Camargo, P.B., Cerri, C.E., Durigan, M., Oliveira Júnior, R.C., Vieira, I.C.G., Barlow, J. 
2014. A large-scale field assessment of carbon stocks in human-modified tropical forests. Glob. Change Biol. doi: 10.1111/gcb.12627

Brown, S., Lugo, A.E. 1990. Tropical secondary forests. J. Trop. Ecol. 6, 1-31.

Burger, D.M., Delitti, W.B.C. 2008. Allometric models for estimating the phytomass of a secondary Atlantic Forest area of southeastern Brazil. Biota Neotrop. 8(4), 131-136.

Burnham, K.P., Anderson, D.R. 2002. Model selection and multimodel inference. A practical information-theoretic approach. Springer, New York.

Butchart, S.H.M., Walpole, M., Collen, B., van Strien, A., Scharlemann, J.P.W., Almond, R.E.A., Baillie, J.E.M., Bomhard, B., Brown, C., Bruno, J., Carpenter, K.E., Carr, G.M., Chanson, J., Chenery, A.M., Csirke, J., Davidson, N.C., Dentener, F., Foster, M., Galli, A., Galloway, J.N., Genovesi, P., Gregory, R.D., Hockings, M., Kapos, V., Lamarque, J.F., Leverington, F., Loh J., McGeoch, M.A., McRae, L., Minasyan, A., Morcillo, M.H., Oldfield, T.E.E., Pauly, D., Quader, S., Revenga, C., Sauer, J.R., Skolnik, B., Spear, D., Stanwell-Smith, D., Stuart, S.N., Symes, A., Tierney, M., Tyrrell, T.D., Vie, J.C., Watson, R. 2010. Global Biodiversity: Indicators of Recent Declines. Science 328, 1164-1168.

Castilho, C.V., Magnusson, W.E. R., de Araújo, N.O., Luizão, R.C.C., Luizão, F.J., Lima, A.P., Higuchi, N. 2006. Variation in aboveground tree live biomass in a central Amazonian Forest: Effects of soil and topography. For. Ecol. Manage. 234, 85-96. 
Chave, J., Condit, R., Lao, S., Caspersen, J.P., Foster, R.B., Hubbell, S.P. 2003. Spatial and temporal variation of biomass in a tropical forest: results from a large census plot in Panama. J. Ecol. 91, 240-252.

Chazdon, R.L., Letcher, S.G., van Breugel, M., Martínez-Ramos, M., Bongers, F., Finegan, B. 2007. Rates of change in tree communities of secondary Neotropical forests following major disturbances. Philos. Trans. R. Soc. B $362,273-289$.

Chinea, J.D. 2002. Tropical forest succession on abandoned farms in the Humacao Municipality of eastern Puerto Rico. Forest Ecol. Manage. 167, 195207.

Chomitz, K.M., Brenes, E., Constantino, L. 1999. Financing environmental services: the Costa Rican experience and its implications. Science of the Total Environment. 240, 157-169.

Cincotta, R.P., Wisnewski, J., Engelman, R., 2000. Human population in the biodiversity hotspots. Nature 404, 990-992

Clark, D.A., Brown, S., Kicklighter, D.W., Chambers, J.Q., Thomlinson, J., Ni, J., Holland, E.A. 2001. Net Primary Production in Tropical Forests: An Evaluation and Synthesis of Existing Field Data. Ecol. Appl. 11(2), 371-384.

Couto, H.T.Z, Vetorazzo, S.C. 1999. Seleção de equações de volume e peso seco comercial para Pinus taeda. Cerne, 5(1), 69-80. 
D’Angelo, S., Andrade, A., Laurance, S.G., Laurance, W.F., Mesquita, R., 2004. Inferred causes of tree mortality in fragmented and intact Amazonian forests. J. Trop. Ecol. 20, 243-246.

Ditt, E.H., Mourato, S., Ghazoul, J., Knight, J. 2010. Forest conversion and provision of ecosystem services in the Brazilian Atlantic Forest. Land Degrad. Develop. 21, 591-603.

Dean, W. 1997. With broadax and firebrand: the destruction of the Brazilian Atlantic forest. London, University of California press, Ltd.

Falkowski, P., Scholes, R., Boyle, E., Canadell, J., Canfield, D., Elser, J., Gruber, N., Hibbard, K., Hogberg, P., Linder, S., Mackenzie, F., Moore, B., Pedersen, T., Rosenthal, Y., Seitzinger, S., Smetacek, V., Steffen, W. 2000. The global carbon cycle: A test of our knowledge of earth as a system. Science 290, 291296.

FAO. 2014. Forest Resources Assessment Programme. Working Paper 83/E. Food and Agriculture Organization of the United Nations, Rome.

Ferraz, S.F.B., Ferraz, K.M.P.M.B., Cassiano, C.C., Brancalion, P.H.S., Luz, D.T.A., Azevedo, T.N., Tambosi, L.R., Metzger, J.P. 2014. How good are tropical forest patches for ecosystem services provisioning? Landsc. Ecol. 29, 187-200.

Ferreira, L.V., Laurance, W.F. 1997. Effects of forest fragmentation on mortality and damage of selected trees in central Amazonia. Conserv. Biol. 11, 797-801. 
Fine, P.V.A. 2002. The invasibility of tropical forests by exotic plants. J. Trop. Ecol. 18, 687-705.

Galindo-Gonzalez, J., Guevara, S., Sosa, V. 2000. Bat- and bird-generated seed rains at isolated trees in pastures in a tropical rainforest. Conserv. Biol. 14, 1693-1703.

Galindo-Leal, C., Gusmão Câmara, I. 2003. Atlantic Forest hotspot status: an overview. In: Galindo-Leal C, de Gusmão Câmara (eds). The Atlantic forest of South America. Island Press, Washington, DC, pp 3-11.

Gardner, T.A., Barlow, J., Sodhi, N.S., Peres, C.A. 2010. A multi-region assessment of tropical forest biodiversity in a human-modified world. Biol. Conserv. 143(10), 2293-2300.

Guariguata, M. R., Ostertag, R. 2001. Neotropical secondary forest succession: changes in structural and functional characteristics. For. Ecol. Manage. 148, 185-206.

Guevara, S., Meave, J., Morenocasasola, P., Laborde, J. 1992. Floristic composition and structure of vegetation under isolated trees in Neotropical pastures. J. Veg. Sci. 3, 655-664.

Guevara, S., Laborde, J. 1993. Monitoring seed dispersal at isolated standing trees in tropical pastures - consequences for local species availability. Vegetation 108, 319-338. 
Guevara, S., Laborde, J., Sanchez-Rios, G. 2004. Rain forest regeneration beneath the canopy of fig trees isolated in pastures of Los Tuxtlas, Mexico. Biotropica 36, 99-108.

Grimm, N.B., Faeth, S.H., Golubiewski, N.E., Redman, C.L., Wu, J., Bai, X., Briggs, J.M. 2008. Global change and the ecology of cities. Science 319, 756760.

Groeneveld, J., Alves, L.F., Bernacci, L.C., Catharino, E.L.M., Knogge, C., Metzger, J.P., Puitz, S. A, Huth, A. 2009. The impact of fragmentation and density regulation on forest succession in the Atlantic rain forest. Ecol. Model. $220,2450-2459$.

Hermann, A., Schleifer, S., Wrbka, T. 2011. The concept of ecosystem services regarding landscape research: a review. Living Reviews in Landscape Research, 5, 1-37.

Hjerpe, J., Hedenas, H., Elmqvist, T. 2001. Tropical rain forest recovery from cyclone damage and fire in Samoa. Biotropica 33, 249-259.

Hoekstra, J.M., Boucher, T.M., Ricketts, T.H., Roberts, C. 2005. Confronting a biome crisis: global disparities of habitat loss and protection. Ecol. Lett. 8, 2329.

Houghton, R. A. 1994. The worldwide extent of land-use change. BioScience 44, 305-313.

Houghton, R.A. 2005. Aboveground Forest Biomass and the Global Carbon Balance. Glob. Change Biol. 11, 945-958. 
Houghton, R.A. 2013. The emissions of carbon from deforestation and degradation in the tropics: past trends and future potential. Carbon Manage. 4, 539-546.

Hughes, R.F., Kauffman, J.B., Jaramillo, V.J. 1999. Biomass, carbon, and nutrient dynamics of secondary forests in a humid tropical region of México. Ecology 80(6), 1892-1907.

IPCC. 2014. Contribution of Working Groups I, II and III to the Fourth Assessment Report of the Intergovernmental Panel on Climate Change. In Climate Change, Synthesis Report, Core Writing Team, Pachauri, R.K. and Reisinger, A. (eds), Geneva, Switzerland.

Joly, C.A., Rodrigues, R.R., Metzger, J.P., Haddad, C.F.B., Verdade, L.M., Oliveira, M.C., Bolzani, V.S. 2010. Biodiversity Conservation Research, Training, and Policy in São Paulo. Science 328 (5984), 1358-1359.

Keller, M., Palace, M., Asner, G.P., Pereira, R., Silva, J.N.M. 2004. Coarse woody debris in undisturbed and logged forests in the eastern Brazilian Amazon. Global Change Biol.10, 784-795.

Laurance, W.F., Laurance, S.G., Ferreira, L.V., Rankinde Merona, J.M., Gascon, C., Lovejoy, T.E. 1997. Biomass collapse in Amazonian forest fragments. Science 278, 1117-1118.

Laurance, W.F., Delamonica, P., Laurance, S.G., Vasconcelos, H.L., Lovejoy, T.E. 2000. Rainforest fragmentation kills big trees. Nature 404, 836. 
Laurance, W.F., Perez-Salicrup, D., Delamonica, P., Fearnside, P.M., D’Angelo, S., Jerozolinski, A., Pohl, L., Lovejoy, T.E. 2001. Rain forest fragmentation and the structure of Amazonian liana communities. Ecology 82, 105-116.

Laurance, W.F., Lovejoy, T.E., Vasconcelos, H.L., Bruna, E.M., Didham, R.K., Stouffer, P.C., Gascon, C., Bierregaard, R.O., Laurance, S.G., Sampaio, E. 2002. Ecosystem decay of Amazonian forest fragments: a 22-year investigation. Conserv. Biol. 16, 605-618.

Laurance, W.F., Camargo, J.L.C., Luizão, R.C.C., Laurance, S.G., Pimm, S.L., Bruna, E.M., Stouffer, P.C., Williamson, G.B., Benítez-Malvido, J., Vasconcelos, H.L., Van Houtan, K.S., Zartman, S.E., Boyle, S.A., Didham, R.K., Andrade, A., Lovejoy, T.E. 2011. The fate of Amazonian forest fragments: A 32-year investigation. Biol. Conserv. 144, 56-67.

Lira, P.K., Ewers, R.M., Banks-Leite, C., Pardini, R., Metzger, J.P. 2012a. Evaluating the legacy of landscape history: extinction debt and species credit in bird and small mammal assemblages in the Brazilian Atlantic Forest. J. Appl. Ecol. 49, 1325-1333.

Lira, P. K., Tambosi, L.R., Ewers, R.M., Metzger, J.P. 2012b. Land-use and land-cover change in Atlantic Forest landscapes. For. Ecol. Manage. 278, p. 80-89. 
Marin-Spiotta, E., Ortertag, R., Silver, W.L. 2007. Long-term patterns in tropical reforestation: plant community composition and aboveground biomass accumulation. Ecol. Appl. 17(3), 828-839.

Martinelli, L.A., Almeida, S., Brown, I.F.,Moreira, M.Z., Victoria, R.L., Filoso, S., Ferreira, C.A.C., Thomas, W.W. 2000. Variation in Nutrient Distribution and Potential Nutrient Losses by Selective Logging in a Humid Tropical Forest of Rondonia, Brazil. Biotropica 32, 597-613.

MEA. 2005. Millennium Ecosystem Assessment Synthesis. In: (eds. Reid, W., Mooney, H.A., Cropper, A., Capistrano, D., Carpenter, S.R., Chopra, K., Dasgupta, P., Dietz, T., Duraiappah Kumar, A., Hassan, R., Kasperson, R., Rik Leemans, R.M., McMichael, T.A.J., Pingali, P., Samper, C., Scholes, R., Watson, R.T., Zakri, A.H., Shidong, Z., Ash, N.J., Bennett, E., Kumar, P., Lee, M.J., Raudsepp-Hearne, C., Henk Simons, T.J., Zurek, M.B. United Nations.

Metzger, J. P. 2009. Conservation issues in the Brazilian Atlantic forest. Biol. Conserv. 142, 1138-1140.

Nascimento, H.E.M., Laurance, W.F. 2002. Total aboveground biomass in central Amazonian rainforests: a landscape-scale study. For. Ecol. Manage. $168,311-321$.

Naughton-Treves, L., Chapman, C.A. 2002. Fuelwood resources and forest regeneration on fallow land in Uganda. J. Sustainable For.14, 19-32. 
Ngo, K.M., Turner, B.L., Muller-Landau, H.C., Davies, S.J., Larjavaara, M., Hassan, N.F.N., Shawn, L. 2013. Carbon stocks in primary and secondary tropical forests in Singapore. For. Ecol. Manage. 296, 81-89.

Numata, I., Cochrane, M.A., Souza Junior, C.M., Sales, M.H. 2011. Carbon emissions from deforestation and forest fragmentation in the Brazilian Amazon. Environ. Res. Lett. 6, 044003-044010.

Paula, M.D, Costa, C.P.A, Tabarelli, M. 2011. Carbon storage in a fragmented landscape of Atlantic forest: the role played by edge-affected habitats and emergent trees. Trop. Conserv. Sci. 4 (3), 349-358.

Piotto, D., Montagnini, F., Thomas, W., Ashton, M., Oliver, C. 2009. Forest recovery after swidden cultivation across a 40-year chronosequence in the Atlantic forest of southern Bahia, Brazil. Plant. Ecol. 205, 261-272.

PROBIO/MMA. 2007. Áreas prioritárias para conservação, uso sustentável e repartição de benefícios da biodiversidade brasileira. Brasília. 301 pp.

Pütz, S., Groeneveld, J., Alves, L.F., Metzger, J.P., Huth, A. 2011. Fragmentation drives tropical forest fragments to early successional states: a modelling study for Brazilian Atlantic forests. Ecol. Model. 222, 1986-1997.

R Development Core Team. 2013. R: A language and environment for statistical computing. R Foundation for Statistical Computing, Vienna, Austria. ISBN 3900051-07-0, Disponível em: URL http://www.R-project.org. 
Ribeiro, M.C., Metzger, J.P., Martensen, A.C., Ponzoni, F.J., Hirota, M.M. 2009. The Brazilian Atlantic Forest: How much is left, and how is the remaining forest distributed? Implications for conservation. Biol. Conserv. 142, 11411153.

Ribeiro, M., Martensen, A., Metzger, J., Tabarelli, M., Scarano, F., Fortin, M.J. 2011. Biodiversity Hotspots: distribution and protection of conservation priority areas. In: The Brazilian Atlantic Forest: a shrinking biodiversity hotspot (eds. Zachos FE \& Habel JC). Springer-Verlag Berlin, pp. 405-434.

Ries, L., Fletcher Junior, R.J., Battin, J., Sisk, T.D. 2004. Ecological responses to habitat edges: Mechanisms, Models, And Variability Explained. Annu. Rev. Ecol. Evol. Syst. 35, 491-522.

Rodrigues, E. 1998. Edge Effects on the Regeneration of Forest Fragments in South Brazil. Ph.D. Thesis, Harvard University, USA.

Rodrigues, R.R., Joly, C.A., Brito, M.C.W., Paese, A., Metzger, J.P., Cassati, L., Nalon, M.A., Menezes, N., Ivanauskas, N.M., Bolzani, V., Bononi, V.L.R. 2008. Diretrizes para conservação e restauração da biodiversidade no Estado de São Paulo. Governo do Estado de São Paulo, São Paulo.

Sanderson, E.W., Jaiteh, M., Levy, M.A., Redford, K.H., Wannebo, A.V., Woolmer, G. 2002. The human footprint and the last of the wild. Bioscience $52,891-904$. 
Sassen, M., Sheil, D. 2013. Human impacts on forest structure and species richness on the edges of a protected mountain forest in Uganda. For. Ecol. Manage. 307, 206-218.

Schnitzer, S.A., DeWalt, S.J., Chave, J. 2006. Censusing and Measuring Lianas: A Quantitative Comparison of the Common Methods. Biotropica 38(5), 581591.

Schumacher, M.V., Witschoreck, R., Calil, F.N., Lopes, V.G., Vieira, M. 2011. Produção de biomassa no corte raso em plantio de Araucaria angustifolia (bertol.) Kuntze de 27 anos de idade em quedas doliguaçu, PR. Ciência Florestal 21(1), 53-62.

Slocum, M., Horvitz, C. 2000. Seed arrival under different genera of trees in a Neotropical pasture. Plant Ecol. 149, 51-62.

Slocum, M. 2001. How tree species differ as recruitment foci in a tropical pasture. Ecology 82, 2547-2559.

Soares, C.P.B., Leite, H.G., Görgens, E.B. 2005. Equações para estimar o estoque de carbono no fuste de árvores individuais e em plantios comerciais de eucalipto. R. Árvore 29 (5), 711-718.

Soares-Filho, B.S., Rajão, R., Macedo, M., Carneiro, A., Costa, W.L.S., Coe, M., Rodrigues, H.O., Alencar, A. 2014. Cracking Brazil's Forest Code. Science 344, 363-364. 
SOS Mata Atlântica, INPE, 2008. Disponível em: URL http://mapas.sosma.org.br

SOS Mata Atlântica. 2014. Atlas dos Remanescentes Florestais da Mata Atlântica- período 2012-2013 - Relatório Técnico. Disponível em: URL http://www.sosma.org.br/wp-content/uploads/2014/05/atlas_2012

2013_relatorio_tecnico_20141.pdf

Tabarelli, M., Aguiar, A.V., Ribeiro, M.C., Metzger, J.P., Peres, C.A. 2010. Prospects for biodiversity conservation in the Atlantic Forest: Lessons from aging human-modified landscapes. Biol. Conserv. 143, 2328-2340.

TEEB. 2010. Mainstreaming the Economics of Nature: A Synthesis of the Approach, Conclusions and Recommendations of TEEB. In: (eds. Sukhdev, P., Wittmer, H., Schröter-Schlaack, C., Nesshöver, C., Bishop, J., Brink, P.T., Gundimeda, H., Kumar, P., Simmons. B). Conference of Parties to the CBD Nagoya, Japan.

Teixeira, A.M.G., Soares, B.S., Freitas, S.R., Metzger, J.P. 2009. Modeling landscape dynamics in an Atlantic rain forest region: implications for conservation. For. Ecol. Manage. 257, 1219-1230.

Thomlinson, J.R., Serrano, M.I., del M. Lopez, T., Aide, T.M., Zimmerman, J.K. 1996. Land-use dynamics in a post-agricultural Puerto Rican landscape (19361988). Biotropica 28, 525. 
Tiepolo, G., Calmon, M., Feretti, M.A. 2002. Measuring and monitoring carbon stocks at the. In: International Symposium on Forest Carbon Sequestration and Monitoring. Extension Serie Taiwan Forestry Research Institute 153, 98-115.

Tilman, D., Balzer, C., Hill, J., Befort, B.L. 2011. Global food demand and the sustainable intensification of agriculture. Proc. Natl. Acad. Sci. U.S.A. 108, 20260-20264.

Veloso, H.P., Rangel Filho, R.A.L., Lima, J.C.A. 2012. Manual Técnico da Vegetação Brasileira, 2 ed. Instituto Brasileiro de Geografia e Estatínstica, Rio de Janeiro, Brasil.

Vieira, S.A., de Camargo, P.B., Selhorst, D., da Silva, R., Hutyra, L., Chambers, J.Q., Brown, I.F., Higuchi, N., dos Santos, J., Wofsy, S.C., Trumbore, S.E., Martinelli, L.A. 2004. Forest structure and carbon dynamics in Amazonian tropical rain forests. Oecologia 140, 468-479.

Vieira, S. A., Alves, L.F., Aidar, M.P.M, Araújo, L.S., Baker, T., Batista, J.L.F., Campos, M.C.R., Camargo, P.B., Chave, J., Delitti, W.B., Higuch, I.N., Honório, E., Joly, C.A., Keller, M., Martinelli, L.A., Mattos, E.A., Metzker, T., Phillips, O.L., Santos, F.A.M., Shimabukuro, M.T., Silveira, M., Trumbore, S.E. 2008. Estimation of biomass and carbon stocks: the case of the Atlantic Forest. Biota Neotropica 8, 21-29.

Vieira, S.A., Alves,L.F., Duarte-Neto, P.J.M, Martins, S.C., Veiga, L.G., Scaranello, M.A., Picollo, M.C., Camargo, P.B., do Carmo, J.B., Neto, E.S., 
Santos, F.A.M., Joly, C.A., Martinelli, L.A. 2011. Stocks of carbon and nitrogen and partitioning between above- and belowground pools in the Brazilian coastal Atlantic Forest elevation range. Ecol. Evol. 1(3), 421-434.

Whately, M., Cunha, P. 2006. Um olhar sobre o maior manancial de água da Região Metropolitana de São Paulo. In. Instituto Socioambiental São Paulo.

Williams-Linera, G., Domiguez-Gastelu, V., Garcia-Zurita, M.E. 1998. Microenvironment and floristic of different edges in a fragmented tropical rainforest. Conserv. Biol. 12, 1091-1102.

Wright, S.J. 2005. Tropical forests in a changing environment. Trends Ecol. Evol. 20, 553-560.

Zuur, A.G., Leno, E.N., Walker, N.J., Saveliev, A.A., Smith, G.M. 2009. Mixed effects models and extensions in ecology with R. Springer, New York.

Willemen, L., Veldkamp, A., Verburg, P.H., Hein, L., Leemans, R. 2012. A multi-scale modelling approach for analyzing landscape service dynamics. J. Environ. Manage. 100, 86-95.

Zarin, D. J., Davidson, E.A., Brondizio, E., Vieira, I.C.G., Sá, T., Feldpausch, T., Schuur, E.A.G., Mesquita, R., Moran, E., Delamonica, P., Ducey, M.J., Hurtt, G.C., Salimon, C., Denich, M. 2005. Legacy of fire slows carbon accumulation in Amazonian forest regrowth. Front. Ecol. Environ. 3, 365-369. 